Tatiana E. Samoilova

$\mathrm{PhD}$ in History of Art

senior researcher

State Tretiakov gallery

e-mail: tsamol@mail.ru

Moscow, Russia

ORCID 0000-0003-0775-9127

\title{
ICON OF THE APOCALYPSE FROM THE DORMITION CATHEDRAL OF THE KREMLIN. DATE AND HISTORICAL CONTEXT
}

Summary: The "Apocalypse" icon from the Domition Cathedral of the Moscow Kremlin has long been in the field of view of researchers, but still there is no common opinion about its dating, and therefore there is no context in which this monument would take its place.

The icon has many inscriptions, all of which correspond to the text of the Revelation of John the Theologian. In the construction of the composition, the master of the "Apocalypse" could not rely on the Byzantine tradition of illustrating the Revelation, since it actually did not exist. So what could the author of the iconography of the Moscow Apocalypse have been inspired by? The process of penetration of Renaissance influences into Russian culture, which began in the reign of Ivan III, reached

The icon "Apocalypse" from the Dormition Cathedral has long been in the field of view of researchers, but still remains a mystery in many aspects. The researchers have no consensus either about the art center to which it belongs, neither about its dating, and, consequently, there is no historical context in which this monument would take its firm place. The range of proposed dates - from the 1480 s to the beginning of the $\mathrm{XVI}$ century at first glance is not too wide, but in this case it is essential to try to understand whether the "Apocalypse" refers to the works of the academic tradition of the late XV century or belongs to another post-Dionysian tradition, which was developed in the first decade of the $\mathrm{XVI}$ century ${ }^{1}$.

1 The main tendency of Russian painting in the late $X V$ th and early XVIth centuries. - academic. It manifests itself in the desire to unify and standardize forms, motives, methods of personal and preparatory writing, methods of compositional construction of scenes developed in painting of the first third of its highest point at the beginning of the XVI century. The coincidence of certain motives of the iconographic program of the «Apocalypse» with the motives of Botticelli's illustrations for the Divine Comedy, as well as the role of the line in both works, indicate the penetration of Renaissance art influences into iconepainting. The discovered parallels do not allow us to date the icon from the Domition Cathedral earlier than 1491-1500, the icon was most likely written after 1500 , in the first decade of the $\mathrm{XVI}$ century. The icon became the "banner" of a new period of understanding of eschatological ideas.

Keywords: Apocalypse, icon, miniature, iconographic program, eschatology, Renaissance influences, iconographic motive, iconography, tradition, art of drawing

The second important question is the place of this icon in the development of the Russian tradition of illustrating the Revelation of John the Theologian in the XV-XVI centuries. I. Kachalova studied this problem most closely ${ }^{2}$. She builds a whole chain of works created on the theme of the Apocalypse. The researcher considers the painting of the Annunciation Cathedral of the Moscow Kremlin, created in

the $\mathrm{XVth}$ century. Brought to the ideal technical perfection they turn into pictorial forms, the combinations of which made it possible to convey the meaning of the most abstract concepts. See: Lifshič L. I. O granice ponyatij "dionisievskij stil'" i "stil' Dionisiya" Drevnerusskoe iskusstvo. Ideya i obraz. Opyty izucheniya vizantijskogo i drevnerusskogo iskusstva: Materialy Mezhdunarodnoj nauchnoj konferencii 1-2 noyabrya 2005 g. ed. A. L. Batalov, E. S. Smirnova M.: Severnyj Palomnik, 2005. P. 130. (in Russian).

2 Kachalova I.YA. Apokalipsis v stenopisi Blagoveshchenskogo sobora Blagoveshchenskij sobor Moskovskogo Kremlya: Materialy i issledovaniya ed. N. S. Vladimirskaya. M.: Gosudarstvennyj istoriko-kul'turnyj muzej-zapovednik "Moskovskij Kreml'", 1999. P. 30-53. (in Russian) 


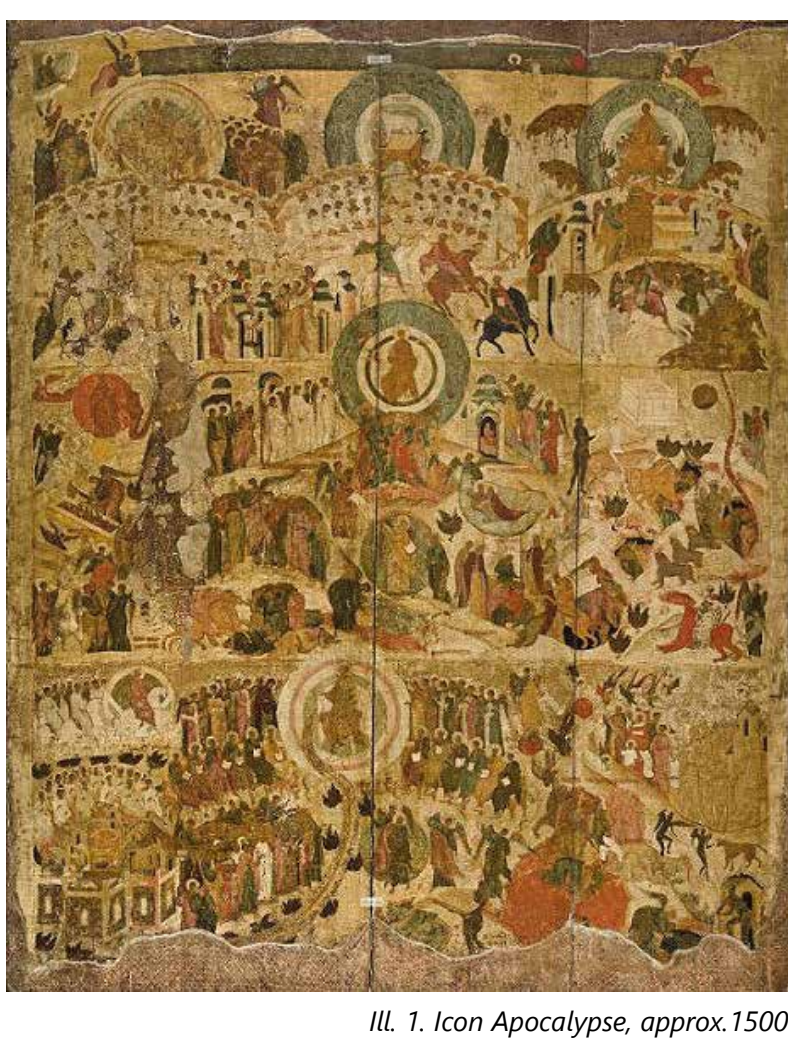

III. 1. I con Apocalypse, approx. 1500

1405 by Theophanes the Greek ${ }^{3}$, containing apoc alyptic plots, to be the starting point of the development of the tradition. I. Kachalova calls the icon "Apocalypse" the next monument in this chain. The researcher believes that it was painted in the 1480 s for the new Fioravanti Cathedral and, from the point of view of iconography, goes back to the painting of Theophanes the Greek, the oldest example of the inclusion of apocalyptic subjects in Byzantine art. This is followed by the painting of the narthex of the Dormition Cathedral, which appeared in 1515 (the narthex was rewritten in the XVII century in accordance with ancient drawings).

The next stage is the painting of the Annunciation Cathedral in 1547, the program of which, according to I. Kachalova's research, is largely based on the iconography of the icon "Apocalypse" 4 . However, I. Kachalova herself, insisting on the idea of painting Theophanes the Greek as the starting poin of the development of the Russian tradition, notes that in view of the theme of Revelation, undeveloped in Byzantine art, only a few selected visions of

3 Kachalova I.YA. Monumental'naya zhivopis' Blagoveshchenskij sobor Moskovksogo Kremalya. K 5 50--letiyu unikal'nogo pamy
atnika russkoj kul'tury. M.:. Iskusstvo, 1990. P. 30. (in Russian) Currently G.P. Chinyakova published another monument the manuscript Apocalypse from the collection of the RS (collection of V.V.F.466. № 6), which she dates back to the 1540s. CHinyakova G. P. Drevnyaya Rus' i Zapad. Russki stenopis'. M.: BuksMArt, 2017. P. 26. (in Russian)
John the Theologian could be included in it ${ }^{5}$. From this point of view, it is difficult to imagine that the painting of 1405 could have a significant impact on the formation of a complex, multilevel program of the icon "Apocalypse". It is also appropriate to recall that in 1416 the Annunciation Cathedral was completely rebuilt. In its place grew another, much more extensive church, which in turn was replaced by the temple of $1489^{6}$. This cathedral, as we remember, was painted in $1508^{7}$. The history of cardinal reconstructions of the Annunciation Church suggests that the memory of Feofan's painting in it could be preserved only nominally. We also have no information about what, from the point of view of the program, the painting of the Annunciation Cathedral of 1508 represented, except the supposition that the painting of 1547 , which decorated the walls of the cathedral after the infamous fire, could to one degree or another repeat the previous one. Some iconographic features of a number of compositions, according to the observations of I. Kachalova, date back to the post-Dionysian epoch ${ }^{8}$. But the iconographic program of painting of the narthex of the Dormition Cathedral (1515) is directly related to the icon, according I. Kachalova's article ${ }^{9}$. Thus, all the facts indicate that it was the icon from the Dormition Cathedral that became the ancestor of the iconographic tradition that developed during the XVI century. Its predecessor could only be a hypothetically existing, but not extant manuscript ${ }^{10}$. In this context, understanding the phenomenon of this monument as absolutely innovative, opening a new era, acquires special significance.

Let's turn to the style of the icon "Apocalypse". Despite the fact that this monument belongs to the Dionysian epoch, its style is strikingly different

Kachalova I.YA. Monumental'naya zhivopis' Blagoveshchenskj] sobor Moskovskogo Kremlya. K 500-letiyu unikal'nogo pamyatnika russkoj kul' tury. M.: Iskusstvo, 1990. P. 30. (in Russian) Kachalova I.YA. Istoriya arhitektury Blagoveshchenskogo sobora 1990. P. 10. (in Russian)

PSRL T. 13. 4. 1. P.9. (in Russian)

Kachalova I.YA. Monumental'naya zhivopis' Blagoveshchenskij sobor Moskovskogo Kremlya. K 500-letiyu unikal'nogo pamyatnika russkoj kul'tury. M.
(in Russian).P.25-27. (in Russian).

Kachalova I.YA. Apokalipsis v stenopisi Blagoveshchenskogo sobora Blagoveshchenskij sobor Moskovskogo Kremlya: Materialy i issledovaniya ed. N. S. Vladimirskaya. M.: Gosudarstvennyj istoriko-kul'turnyj muzej-zapovednik "Moskovskij Kreml"

Chinyakova G.P. Drevnyaya Rus' Zapad. Russkij licevoj ApoM.: BuksMArt, 2017. P. 29. (in Russian) from the painting of the famous icon painter. The most accurate description of the style of Dionysius belongs to L. Lifshits ${ }^{11}$. He highlights such significant features as the complete subordination of the rhythmic structure of the composition to the plane exquisite contour drawing, strong angles and elongation of proportions as opposed to flattened forms, the complete absence of the effect of chiaroscuro and any dramatic tension in the faces and figures, the lack of connection of gestures and movements with a specific action, as elevation above all worldly. The masters of the time that came after Dionysius tried to follow the path he had trodden, but the height of his individual style was unattainable.

In the works of his followers, the features of $\mathrm{Di}$ onysius' style were objectified on the basis of the academic tradition of the XV century, and along this way the importance of spatial caesuras and their rhythm decreases in art, the figures gradually separate from the background, and their gestures become more realistic ${ }^{12}$. If from this point of view, we compare the masterpiece of the master of the "Apocalypse" with the works of late Dionysius or post-Dionysius painting, it becomes obvious that his style does not fit into either framework. He is absolutely unique, and by the power of talent, as many researchers have noted, he is congenial to Dionysius ${ }^{13}$. His art is distinguished by the previously unseen virtuosity and lightness of the drawing created by the free brush of an experienced miniaturist. The color of his work is almost watercolor transparent, and the degree of transparency is such that the graphic sounds on a par with the picturesque, and the preparatory brush drawing, shining through the transparently laid color acquires the most important value in the style of the icon. The figures of the master of the "Apoc-

11 Lifshič L.I. O granice ponyatij "dionisievskij still" i " stil' Dion isiva" Drevnerusskoe iskusstvo. Ideya i obraz. Opyty izuchenidunarodnoj nauchnoj konferencii 1-2 noyabrya $2005 \mathrm{~g}$. ed. A. L. Batalov, E. S. Smirnova M.: Severnyj Palomnik, 2005 P. 132. (in Russian).

12 Lifshic L. I. O granice ponyatij "dionisievskij stil'" i "stil' Dionisiya" Drevnerusskoe iskusstvo. Ideya i obraz. Opyty izucheniya vizantijskogo i drevnerusskogo iskusstva: Materialy MezhA. L. Batalov, E. S. Smirnova M.: Severnyj Palomnik, 2005 P. 155-156. (in Russian).

13 Lifshič L.I. O granice ponyatij "dionisievskij still" $i$ "stil' Dionisiya" Drevnerusskoe iskusstvo. Ideya i obraz. Opyty izucheniya vizantijskogo i drevnerusskogo iskusstva: Materialy Mezhdunarodnoj nauchnoj konferencii $1-2$ noyabrya $2005 \mathrm{~g}$. ed
A. L. Batalov, E. S. Smirnova M.: Severnyj Palomnik, 2005 . A. 144. (in Russian).

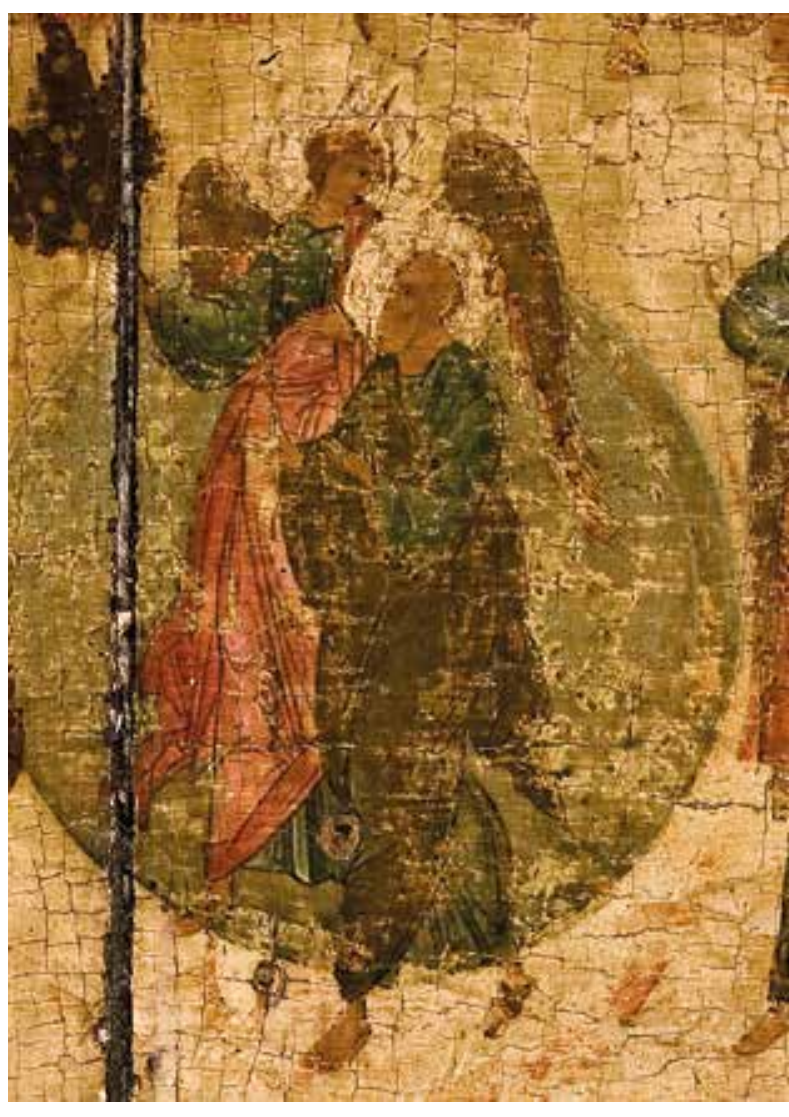

11. 2. Icon Apocalypse, approx 1500 . Fragment.
Angel leads John the Theologian

alypse" are as elegant as those of Dionysius, they also have elongated proportions, but their plasticity, as well as the space in which they are located are almost tangible. Every movement, every gesture is distinguished by an unprecedented plastic naturalness, and in the construction of architectural forms, both their spatiality and the crystal precision of each compartment amazes.

Especially impressive is the image of Heavenly Jerusalem, a city surrounded by a high wall, in each strand of which an image of an angel is placed in the window opening. The master of the "Apocalypse" shows incredible skill in constructing numerous mise-en-scenes, each of which becomes true masterpiece, whether it is the image of an angel barely restraining a figure of the Wind, depicted leading a philosophical conversation with an elder in white robe, or the battle of the angels-horsemen with the forces of evil. The composition of the icon includes many scenes and figures, but at the same time does not lose in integrity, and according to the general opinion of all researchers who wrote about it, it is a "bright image of future bliss", depicting not 
so much the horrors of the last act of world history as the joy and glory gained by the righteous ${ }^{14}$.

The whole drama of the Apocalypse is presented in three acts - three grandiose paintings arranged in three tiers. In the upper one we see the Heaven of heaven - in three rows of round glories, the Lord of Hosts, the Lamb and Christ the Almighty are represented, over which the angels spread the scroll of the New Heaven. The compositional center of the middle tier is Glory with Christ-Emmanuel. This tie presents the most dramatic moments of the universal battle of Good and evil. Here we see the whore of Babylon, crumbling cities, angels gathering a terrible harvest, apocalyptic beasts devouring nations.

The third, lower tier shows a picture of the triumph of the just Judgment taking place with Christ-Emmanuel in the center. From the base of His throne the river of Life flows towards the Heavenly Jerusalem, and on its sides are the righteous and sinners. Despite the presence of three pronounced registers of composition, the boundaries between them are conditional. Such mise-en-scenes are inserted into the picture of each tier, the action of which develops with the transition from tier to tier and clearly indicates their permeability. So, in the upper register, apocalyptic horsemen gallop along the arc of the mandorla of Christ from the second tier, and the angelic host throws fallen angels from the Sky, from which a bloody stream with shooting stars flows to the earth in the second register.

And vice versa, from the second register, the Woman Overcoated in the sun, fleeing from the dragon, aspires upward, and in the upper tier we see her already in white robes, sitting on the throne, established under the Glory of Christ the Almighty. The most important compositional device of the master is the presence in all tiers of the repeatedly repeated figure of testis, a witness, a kind of lyrical hero, namely John the Theologian himself through whose eyes we contemplate all the presented scenes, traveling with him from tier to tier. First, the angel hands John the book of Revelation received from the hands of Christ Himself, and the apostle goes on a mystical journey through the icon. We see John in heaven having a conversation with an elder, revealing to him a picture of the glory of Christ the Almighty. We see how the angel shows 14 Ikony Uspenskogo sobora Moskovskogo Kremlya. Vtoraya polovina XV-XVV vek. Katalog. M... Federal hoe gosudarstvennoe iko-kul'turnyj muzej-zapovednik «Moskovskij Kreml'"», 2016. P. 132. (in Russian)
John the Wife who escaped from the dragon and sits on the throne in the villages of Christ.

In the middle tier, the Angel guides the apostle in the midst of all the apocalyptic horrors of the earthly drama and directs him upwards, pointing to the Wife, Overclothed in the sun, running away from the dragon. In the lower case, John is depicted twice. In the first, he walks with an Angel along the river of Life, in the second, an Angel and John stand under the walls of Heavenly Jerusalem and look at the righteous in white robes sitting in the middle of it. It is remarkable that two young characters in Russian princely hats are singled out among the righteous. These are Boris and Gleb, the saints, representatives of Russian holiness among the universal holiness. There are quite a lot of inscription on the icon, and they mostly correspond to the tex of the Revelation of John the Theologian. We note here that the Revelation ${ }^{15}$. The history of the study of the icon is described in detail in the Catalog of icons of the Dormition Cathedral in $2017^{16}$. I. Kachalova, cited here all the dates put forward by different authors, but stopped at the date proposed by L. Lifshits - the 1480s, believing that the icon was painted for the newly (1479) built Dormition Cathedral. The dating put forward by E. Smirnova also agrees with this opinion. However, there is no consensus among these researchers in the selection of analogies. Thus, E. Smirnova brought the style of the master of the "Apocalypse" closer to the style of miniatures of the Book of the Prophets dated $1489{ }^{17}$, while L. Lifshits believes that the miniatures of the Book of the Prophets lack the Hellenic grace that the images of the icon "Apocalypse" breathe and the features of graphic stylization of the plastic form are more sharply manifested in them. As an analogy to the "Apocalypse", the researcher cited the miniatures of the manuscript of Novgorod origin - namely, the "Apostle" (SHM), dated abroad in the $70 \mathrm{~s}-80 \mathrm{~s}$ of the XV century, emphasizing that the master who wrote the miniatures of this manuscript could be an older contemporary of Diony-

15 Ikony Uspenskogo sobora Moskovskogo Kremlya. Vtoraya polovina XV-XVI vek. Katalog. M.: Federal'noe gosudarstvennoe byudzhetnoe uchrezhdenie kul'tury «Gosudarstvennyy istor-
iko-kul'turnyj muzej-zapovednik «Moskovskij Kreml') 2016. P. 131. (in Russian)

16 Ikony Uspenskogo sobora Moskovskogo Kremlya. Vtoraya polovina XV-XVI vek. Katalog. M.. Federal'noe gosudarstvenno byudzhetnoe uchrezhdenie kul'tury «Gosudarstvennyj istoriko-kul'turnyj muzej-zapovednik «Moskovskij Kreml'», 2016
P. 120-134. (in Russian).
Smirnova E. S. Moskovkaya ikonopis' XIV-XVIII vekov. L.: Avrora, 1988. C. 36., 296-297. (in Russian)
res sius ${ }^{18}$. However, a comparison of the miniatures of the "Apostle" and the icon, as it seems to us, shows that the style of the master of the "Apocalypse" has gone much further from them both in Hellenic grace and in virtuosity of possession of the line. G. Popov inclines to a somewhat later dating of the "Apocalypse" - about $1500{ }^{19}$. The analogies he cites relate to the beginning of the XVI century: miniatures of the Psalter with the ascension of 1502 from the Joseph-Volotsky Monastery (SHM. The Eparch. 81), the Ladder of John of Sinai of the beginning of the XVI century from the Trinity-Sergius Lavra (RSL, f.304. No. 162) ${ }^{20}$ and a collection with the facial texts of the Walk of John the Theologian and the Lives of Boris and Gleb of the last quarter of the XV- beginning of the XVI century (St. Petersburg IIRAN, Archive. Call.238. Op.1. No.71) ${ }^{21}$. The closest to the icon "Apocalypse", in our opinion, are the miniatures of the last manuscript, in which tall thin figures are painted with a free brush and only slightly tinted with liquid paint It should be noted that M. Alpatov, one of its earliest researchers, dated the icon to the beginning of the $1500 \mathrm{~s}^{22}$. G. Chinyakova, a researcher of the iconographic tradition of illustrating the Apocalypse, believes that the icon could have been created after $1500^{23}$. Despite the differing dates, all researchers agree that the icon of the "Apocalypse" marked the beginning of a different from Dionysian style direction. Nevertheless, the problem of the genesis of the style of the master of the Apocalypse remains unsolved. If in the case of Dionysius, despite all the individuality of the master's style, his genetic

18 Lifshič L.I. O granice ponyatij "dionisievskij stil" I" i "stil' Dionislya "Dretnensskoe isk

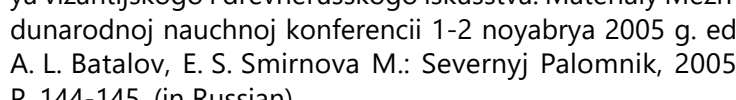
P. 144-145. (in Russian)

19 Popov G.V. ZHivopis' i miniatyura Moskyy serediny XV- nacha-

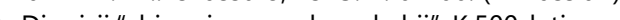

isiz v sobore Rozhdestva Bogorodicy Ferapontovisi Diontyrya: Vystavka proizvedenii drevnerusskogo iskusstva XV-XV w. iz sobranij muzeev i bibliotek Rossii: Katalog. M.. Severny palomnik, 2002. Cat.№ 65. (in Russian).

Dionisij, zhivopisec preslovushchij. .K 500-letiyu rospisi Dionisiya $v$ sobore Rozhdestva Bogorodicy Ferapontova monasW. iz sobranij muzeev i bibliotek Rossii: Katalog. M. Severny palomnik, 2002. Cat.№ 67. (in Russian).

22 Alpatov M.V. Pamyatnik drevnerusskoj zhivopisi XV veka ikoa «Apokalipsis» Uspenskogo sobora Moskovskogo Kremlya. M.: Iskusstvo, 1964. (in Russian)

23 Chinyakova G.P. Drevnyaya Rus' i Zapad. Russkij licevoj ApoM.: BuksMArt, 2017. 374 p. P. 24. (in Russian) connection with the art of Andrei Rublev is obvious, then where the art of the master of the Apocalypse came from is not clear. M. Alpatov believed that he belonged to Moscow culture, but saw in him the influence of Novgorod. What art features of the master of the "Apocalypse" can be called Novgorod? Al researchers agree that this is the primacy of a lin that builds a form in the most detailed way, which is not covered by color. In Novgorod, at the end of the XV and early XVI centuries, a similar graphic style manifested itself primarily in the art of miniatures (The Ladder of John the Ladder with the Words of Cassian the Roman and the hermit Philemon (Pogodinskaya Ladder, RNL, Pogod. 1058,1480s), The Apostle (Likhachevsky Apostle, Institute of History of the Russian Academy of Sciences. Archive, call.238. Op.1, 32741490 s - early 1500s) ${ }^{24}$. These manuscripts came from the scriptorium of the Novgorod Archbishop's house, which developed at the end of the XV century under the leadership of Archbishop Gennady, and then after 1523 - under the auspices of Archbishop Makarii. It should be noted that both Archbishop Gennady and Makarii were Moscow's henchmen, "agents of autocratic power," as A. Nekrasov wrote about them ${ }^{25}$. In the Novgorod scriptorium at that time, Moscow masters who came with the archbishop and local Novgorodians worked side by side, exerting influence on each oth er ${ }^{26}$. As we can see from the example of the Book of the Prophets, the graphic style was not alien to Moscow art ${ }^{27}$. It is curious that most manuscripts of this time are attributed as Novgorod or Moscow according to the place of housing of the book, but this attribution principle does not always work, since the manuscript could belong to the brush of both Novgorod and Moscow masters.

24 Smirnova E.S. Iskusstvo knigi v srednevekovoj Rusi. Licevye rukopisi Velikogo Novgoroda. XV vek. M.: Severnyj Palomnik 2011. Cat.№ 15, 19. (in Russian)

itel'noe iskusstvo. $M$ Smirnova E. S. Iskusstro knigiv

Smirnova E.S. Iskusstvo knigi v srednevekovoj Rusi. Licevye
rukopisi Velikogo Novgoroda. XV vek. M.: Severnyj Palomnit 2011. C. 142-144, 159. (in Russian). Gordienko E. A. Novgorod $\checkmark$ XVI veke i go duhovnaya zhizn'. SPb.: Dmitrij Bulanin (DB) 2001. P.44-48. (in Russian). Skrynnikov R. G. Gosudarstvo icerkov' na Rusi
150 . (in Russian).

27 Researchers note the graphic style in the Moscow tradition no only in miniatures. So, M. A. Orlova considers the icon "Christmas" from the collection of $\mathrm{P}$. Korin of the late $15^{\text {th }}$ century to be the best example of a high style, which M. Alpatov cied as a close analogy to the icon "Apocalypse". See.: Orloiskusstvo. XIV-XV vv. ed. O. I. Podobedova. M.: Nauka, 1984 P. 253-266. (in Russian). 


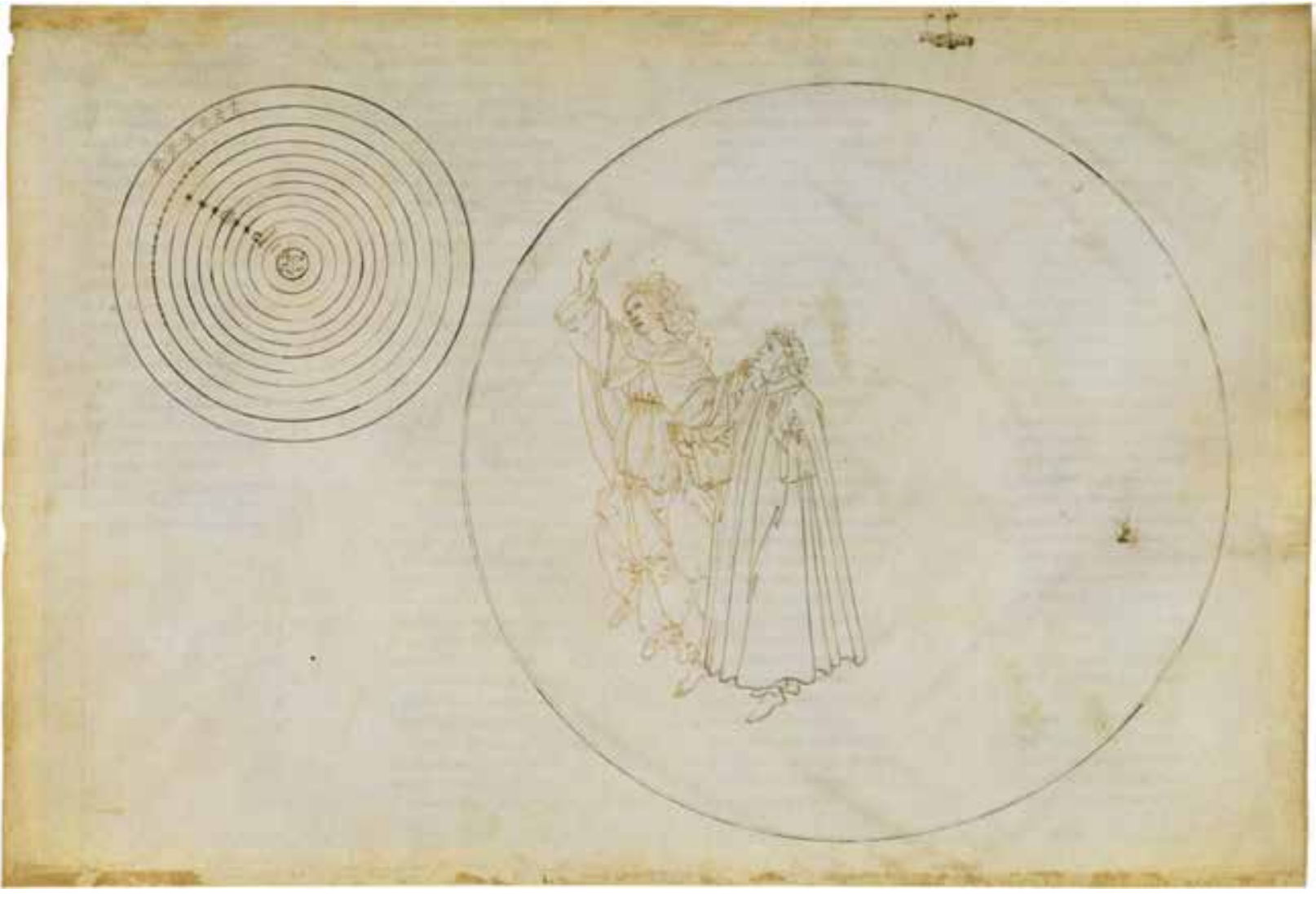

III. 3. Illustration by Sandro Botticelli for Dante's Divine Comedy
Dante and Beatrice. 1481-1500

The Novgorod scriptorium at the turn of the XV- ing example in miniature is the "Life of Nifont" (SHM $\mathrm{XVI}$ centuries was an outstanding phenomenon. Here translators who came from different lands, including from the West, such as the Dominican monk Benjamin, worked on translations of the Bible, the Revelation of John the Theologian and other works along with Russian scribes ${ }^{28}$. We have every reason to assume that invited masters-miniaturists of Western training could also work here. The special creative atmosphere that prevailed in the scriptorium allowed the masters to learn from each other. It is no coincidence that $\mathrm{M}$. Alpatov, in connection with the icon "Apocalypse", spoke about a Moscow master who was influenced by Novgorod, but at the same time did not deny the possibility of Moscow's influence on Novgorod ${ }^{29}$. Through the art of book miniatures, the Moscow school really had a huge impact on Novgorod, softening the sharp energetic style of the Novgorod tradition, making it more refined. This direction continued to develop in Novgorod, and in the time of Makarii was transformed into the so-called Makariev school. Its strik28 Gordienko E.A. Novgorod v XVI veke i ego duhovnaya zhizn SPb.: Dmitrij Bulanin (DB), 2001. P. 44. (in Russian).

Alpa tov M. M. Pamyatnik drevnerusskoj zhivopisi XV veka ikoM.: Iskusstvo, 1964.P.104. (in Russian) the 30s of the XVI century), in which, by the way, A. I. Nekrasov also saw Western influences ${ }^{30}$. Thus, it is likely that the "graphic style" was originally a Moscow phenomenon, but it was in Novgorod that and we cannot exclude that the master of the "Apocalypse" belonging to Moscow culture, whose writ ing style exposes an experienced minaturist, was associated with the scriptorium of the Novgorod archbishop's house. The idea of the influence of Western engravings on the miniature of the Grozny time has already been firmly established in science ${ }^{31}$. of the XVI century are a less developed problem although these influences have been noted by number of researchers. M. Alpatov saw the presence of Renaissance features in the icon "Apocalypse" ${ }^{32}$. They manifested themselves first of all in

30 Nekrasov A.I. Drevnerusskoe izobrazitel'noe iskusstvo. M. Izogiz, 1937. P. 270-271. (in Russian).

Nevolin YU.A. Novoe o kremlyovskih hudozhnikah miniatyuristah i sostave biblioteki Ivana Groznogo Sovetskie arhivy, 1982, № 1. P. 68. (in Russian)

32 Alpatov M.V. Pamyatnik drevnerusskoj opisi XV veka ikona M.: Iskusstvo, 1964. P. 79-80. (in Russian). he found fertie ground for his further development, But Western influences in painting at the beginning the incredible plastic freedom of all the characters, as well as in special attention to the smallest de tails, to facial expressions and gestures, conveyed with rare authenticity and persuasiveness. Can we assume that the graphic manner of the master is also associated with the influence of Western art? It is well known that drawing in the Renaissance was given an important place in the system of teaching painting, and the significance of the sketch, drawing in this period grows to its comprehension as an almost independent work. In this context, it is appropriate to recall the slightly colored drawings of Jean Fouquet, which served as a preparatory stage for the creation of painting portraits (the heyday of the work of this French master fell in the second half of the XV century) ${ }^{33}$. Russian art at the end of the XV- beginning of the XVI centuries may have produced such paintings, where the graphic principle prevails (the Book of the Prophets, the Life of Boris and Gleb) ${ }^{34}$, was a kind of Russian response to the European trend of the development of drawing as an independent art form. Interestingly, in the famous Pogodin Gospel (RNL), miniatures depicting Evangelists are painted in the classical style for the post-Dionysian time - this is a beautiful multi-layered complex painting. But the symbols of the evangelists (Eagle, Lion, Angel, Taurus), placed as the top of the screensavers of the Byzantine style are written completely differently ${ }^{35}$. They are dominated by a line that shines through the transparently laid paint the undertone. These miniature images also differ in spirit from the "portraits" of the evangelists. They have characteristic gestures, facial expressions, there is no lyrical idealization in them, in their images we feel a different non-Byzantine beginning. It seems that an unknown master, playfully, as if by the way, supplemented the strict architecture of the screensavers with his almost careless, but masterfully accurate drawings in every detail. Both in style and technique of execution, these miniature images of the symbols of the evangelists are comparable to the icon "Apocalypse" from the Dormition Cathedral

33 Zolotova E. YU. ZHan Fuke. M.: Izobrazitel'noe iskusstvo, 1986 (in Russian).

34 Dionisij "zhivopisec preslovushchij". K 500-letiyu rospisi Dionisiya v sobore Rozhdestva Bogorodicy Ferapontova monastyrya: Vystavka proizvedenij drevnerusskogo iskusstva XV-XV

35 RNL. Pogod.133. F.10 o6. F.12.F. 173. F.110.F.273.

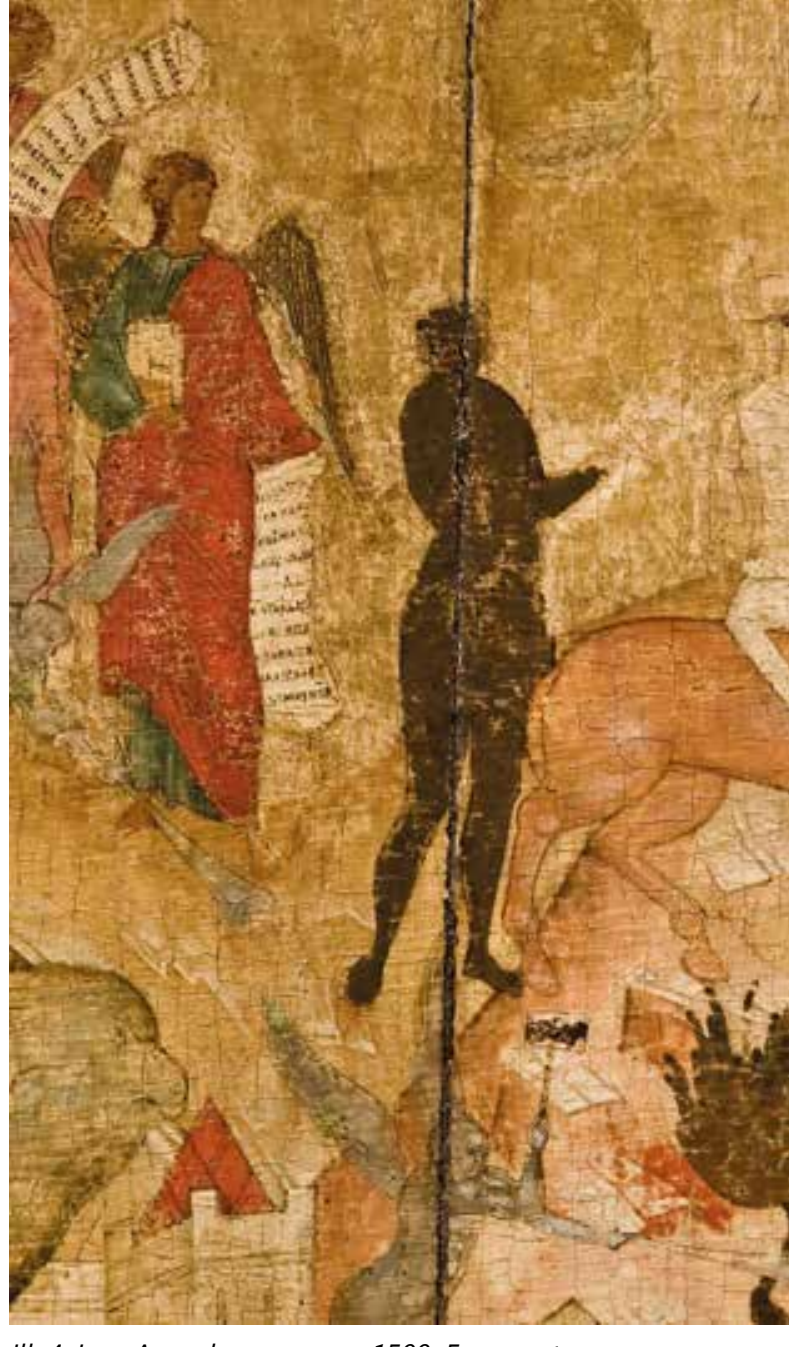

IIl. 4. Icon Apocalypse, approx.1500. Fragment.

and can serve as a close, though not entirely ac curate analogy to it. Of course, the mastery of the author of the "Apocalypse" remains an unattainable height, but this analogy, as well as the analogies given by G. Popov, allow, it seems to us, to return to the discussion of the problem of dating the "Apocalypse" from the Assumption Cathedral to the beginning of the XVI century. Apocalyptic sentiments, as is known, colored the last years of the reign of Ivan III, when society lived in anticipation of the end of the world, scheduled for 1492 36. The response of the epoch to the premonitions of the end of the world in the art of the $80 \mathrm{~s}$ and $90 \mathrm{~s}$ of the XV century was, firstly, the completion of the formation of a high iconostasis with the icon of the Savior in the forces as the central image of the deesis tier, and secondly, the saturation with new motifs of the traditional ico-

36 Alekseev A.I. Pod znakom konca vremen: Ocherki russkoj reli- 
nography of the "Last Judgment" ${ }^{37}$. But perhaps the most striking phenomenon of the time was the birth of a new iconography, called "Rejoices about You." In it, one of the motifs of the composition "The Last Judgment" was transformed into the image of Heavenly Jerusalem ${ }^{38}$. Note that all these works were not connected textually with the Revelation of John the Theologian, although the text of the Apocalypse was known to the ancient Russian scribes. However, in the ancient manuscripts that have come down to us, it is always explained trough the interpretations of Andrew of Caesarea. The earliest sample of the complete text of the Apocalypse without interpretations in the Church Slavonic language contains the Moscow Codex of the New Testament from the Chudov Monastery, dating from the second half of the XIV century. G. Vzdornov believes that this manuscript, written in Constantinople, appeared in Russia at the end of the XIV century, but did not receive a wide response ${ }^{39}$. In 1499, the full text of the Revelation was included in the Bible of Archbishop Gennady ${ }^{40}$. Such a significant event could hardly have gone unnoticed in the world of bookishness and scribes, and in this context it is significant that the icon from the Assumption Cathedral is the first work of iconography containing detailed inscriptions quoting the Revelation of John the Theologian. The Master of the Apocalypse could not rely on the Byzantine tradition of illustrating Revelation, since it actually did not exist. The apocalyptic series of engravings by Albrecht Durer appeared in 1496-1498, and as we know, the influence of Durer's iconography manifested itself for the first time in Russian art only in the middle of the XVI century in the frescoes of the Annunciation Cathedral (the image of an angel on

37 Evseeva L.M. Eskhatologiya 7000 goda i vozniknovenie vysokogo ikonostasa lkonostas. Proiskhozhdenie - Razvitie - Simvolika ed. A. M. Lidov. M..: Progress-Tradiciya, 2000. P. 411 427. (in Russian). Shalina I.A. Drevnejshaya pskovskaya ikona «Strashnogo suda» $V$ sozvezdin L'va. Sbornik statej po ed. M. A. Orlova. M.: Gosudarstvennyj institut iskusstvoznaniya, 2014. P. 538-579. (in Russian)

38 Nersesyan L.V K voprosu o proiskhozhdenii i simvolicheskom soderzhaniii "O Tebe raduetsya" Drevnerusskoe iskusstvo: $V$ Gra (DB), 1999. P. 394. (in Russian).

39 Vzdornov G.I. Rol' slavyanskij monastyrskih masterskih pis'ma Konstantinopolya i Afona v razvitii knigopisaniya i hudozhestvennogo oformleniya russkih rukopisej na rubezhe XIV-XV W.I//TDRRL. Otv. red.. D. S. Lihachev. L., 1968. T.23. S.176.
(in Russian).

ya enciklopediya. T.10. S.584. fiery legs) ${ }^{41}$. The interpretation of the text by the master of the "Apocalypse" also differs from the earlier Western tradition, known to us from such monuments as the Trier and Bamberg Apocalypse 42. From the point of view of the narrative content, the icon from the Dormition Cathedral is much closer to the tapestries of the Angers Apocalypse of 1373 $1381^{43}$. At least, the image in the upper tier of the icon, along with the Sabaoth and Christ the Almighty Lamb, surrounded by elders, attracts attention, which is, of course, a tribute to Western tradition. So what could the author of the iconography of the Moscow Apocalypse be inspired by? After the predicted Doomsday hadn't in 1492, the society did not quit the apocalyptic mood, but they began to develop in a slightly different direction. In 1499, the German mathematician Stofler published his new prediction of a worldwide flood, which he set fo 1524. His published predictions quickly spread not only across Europe, but also penetrated into Rus sia. Their popularization in Russia was promoted by Nikolai Bulev. A native of Lubeck, who received university education, Nikolai Bulev first appeared in Russia as part of the embassy of Georg von Thurn in 1490 and stayed for some time in Novgorod, as he received an order from Archbishop Gennady to compile new Easter tables. At the very beginning of the XVI century (after 1504), Bulev found himself at the papal court, and in 1508 he returned to Russia where he became the court physician of the Grand Duke. In his writings, he promoted not only astrology, but also proved the advantage of the Catholic dogma of Filioque, acting as a catalyst for the development of Russian theological thought. Orthodox scribes had to enter into a polemic with this representative of the Western world ${ }^{44}$ One of the earliest Russian works on the theme of the Doom day was "The Legend of the Seventh Thousand Years" by Joseph Volotsky, where he convinces his read ers that the last dates are known only to the Divine

41 Kachalova I.YA. Apokalipsis v stenopisi Blagoveshchenskogo sobora Blagoveshchenskij sobor Moskovskogo Kremlya: Materialy i issledovaniya ed. N. S. Vladimirskaya. M.: Gosudarstvennyj istoriko-kul'turnyj muzej-zapovednik "Moskovskij Kreml" 42 Zorich A Apokslipsisy IX-XI vv. //https://www.medievalmu seum.ru/01mss/medieval codexes apocalipsi.htm

Giraud-Labalte, Claire: Der Wandteppich der Apokalypse. Rennes 1982.

44 Bulanin D.M. Bulev (Byulov) Nikolaj. // Slovar' knizhniko i knizhnosti Drevnej Rusi. V. 2. 2-ya polovina XIV - XVI v. CH 1.L., 1988. Siničyna N.V. Tretij Rim: istoki i evolyuciya russkoj
srednevekovoj koncepcii (XV-XVI vv.). M. Indrik, 1998. P. 176 226. (in Russian).
Son Himself and are not open to the apostles or even angels ${ }^{45}$. In his essay, Joseph repeatedly refers to the Rejection of John the Theologian, but does not quote directly. Joseph's banner was taken up by other scribes. A peculiar result of this work was the famous Epistle of the elder Philotheus to Misyur-Munekhin (1524), where, continuing the polemic with Boolev, he created a picture of the cosmos ordered by the Divine will, solid and unchangeable, subordinated not to the movement of the stars, but to the plans of divine house-building ${ }^{46}$. Thus, the peak of interest in the topic of the Doomsday falls precisely on the period from the end of the XV century to 1524. It was during this period that a number of images of "John the Theologian on Patmos" appeared in Russian art, in which he is represented dictating a Revelation to his disciple Prokhor. These are the icons "The Apostle John the Theologian on Patmos with walking" from Dmitrov (CMNAR) of the late XV century ${ }^{47}$, the icons of the same name of the beginning of the XVI century from the Trinity Church in (GTG), from the collection of I. S. Ostroukhov (GTG) ${ }^{48}$, from the Vologda Church on Toshna (VSHAMZ) ${ }^{49}$. The icon of the Apocalypse from the Assumption Cathedral naturally falls into this context of special interest in the apocalyptic theme, but at the same time represents a deeply peculiar, unlike anything else, response to the challenge of the era. In this work, not the image of planetary destruction and intimidation was created, but the image of the indestructible Divine cosmos and victory over chaos.

The process of penetration of Renaissance in fluences into Russian culture, which began in the reign of Ivan III, reaches its apogee at the beginning of the XVI century, in the last years of the

45 Alekseev A.I. O «Prosvetitele» i poslaniyah losifa Volockogo// Vestnik cerkovnoj istorii. 2008. № 2 (10). P. 121-220. (in Russian). The author dates the creation of the "«Prosvetitel'» to

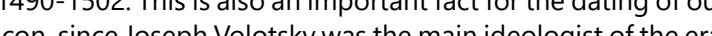
his works became programmatic for icon painters. 46 Siničyna N.V. Tretij Rim: istoki i evolyuciya russkoj sredneve-
kovoj koncepcii (XV-XVI vv.). M.: Indrik, 1998. P.226. (in Russian).

47 Central'nyj muzej drevnerusskoj kul'tury i iskusstva imeni Anreya Rubleva. Ikony Moskvy XIV-XVI wv. Red-sost. L. M. Ev (in Russian)

48 Dionisij "zhivopisec preslovushchij". K 500-letiyu rospisi Dionisiya v sobore Rozhdestva Bogorodicy Ferapontova monastyrya: Vystavka proizvedenij drevnerusskogo iskusstva XV-XV w. iz sobraniij muzeevi bibliotek Rossii: Katalog. M.: Severny,
palomiki, 2002. Cat.№ 48. P.191. (in Russian).

49 Palomnik, 2002. Cat.№ 48. P.191. (in Russian).
Ikony Vologdy XIV-XVI vekov. M., 2007. Kat.№ 35. S.271-281, reign of Ivan Vasilyevich and the first years of the reign of his son Vasily III. The presence of Nikolai Bulev at the Grand Ducal court in 1508 speaks for itself. Bulev, as we remember, in the 1480s was at the papal court in Rome, the largest center of Renaissance culture, where in 1480-1481, at the in vitation of Pope Sixtus, the best masters of Italy worked, including, for example, Sandro Botticelli. These facts are important to us because they confirm the existence of channels through which the influences of Italian art could penetrate into Rus sia. In the 1490s, Savonarola raised his voice in It aly, calling for repentance. In anticipation of the end of time, many Renaissance artists fall under the influence of this preacher, abandoning the values of humanistic culture and turning their eyes to the Church. One of them was Botticelli. During thi period, he created one of his most significant and innovative works - illustrations for Dante's Divine Comedy (1492-1500), executed in a new graphic technique (metal pin, pen). Botticelli turned to Dante's illustration earlier, in 1481. Then, according to his drawings for "Hell", engravings were made for the printing edition ${ }^{50}$. Botticelli's drawings fo the Divine Comedy differ in style from his early, classical Renaissance works. The main thing that the researchers note is the absence of a mathematically grounded perspective construction characteristic of the Renaissance. Three-dimensionality in them is conveyed primarily by the combination of graphic plans and foreshortening of figures. In his drawings we see the unclosed movement of circular lines, images of spheres "with almost im material outlines" ${ }^{51}$. They clearly indicate that un der the influence of the new religious wave, the art of the Renaissance master has changed and become more irrational. It is easy to imagine that it could find a lively response among the masters remaining in the old, medieval system, such as the master of the "Apocalypse" from the Dormition Cathedral, who also conveys three-dimensionality primarily through the connection of graphical-

50 https://www.britannica.com/biography/Sandro-Botticelli/ Late-works

Frank Zöllner Sandro Botticelli als Apelles und als Grisaillemalferentialität der Malerei?: Kunst und Theorie des Helldunkel 1300-1550// Chiaroscuro als ästhetisches Prinzip. Kunst und Theorie des Helldunkels 1300-1550, ed. by Claudia Lehmann Berlin N Gew York et al : de Gruyter, 2018 . Homas Dittelbach Berlin, New York et. al.: de Gruyter, 2018. Herbert Horne, Bot-
ticelli: Painter of Florence Florenz:S S. PS. 1986 http://www bnetti.ru/content/1047 


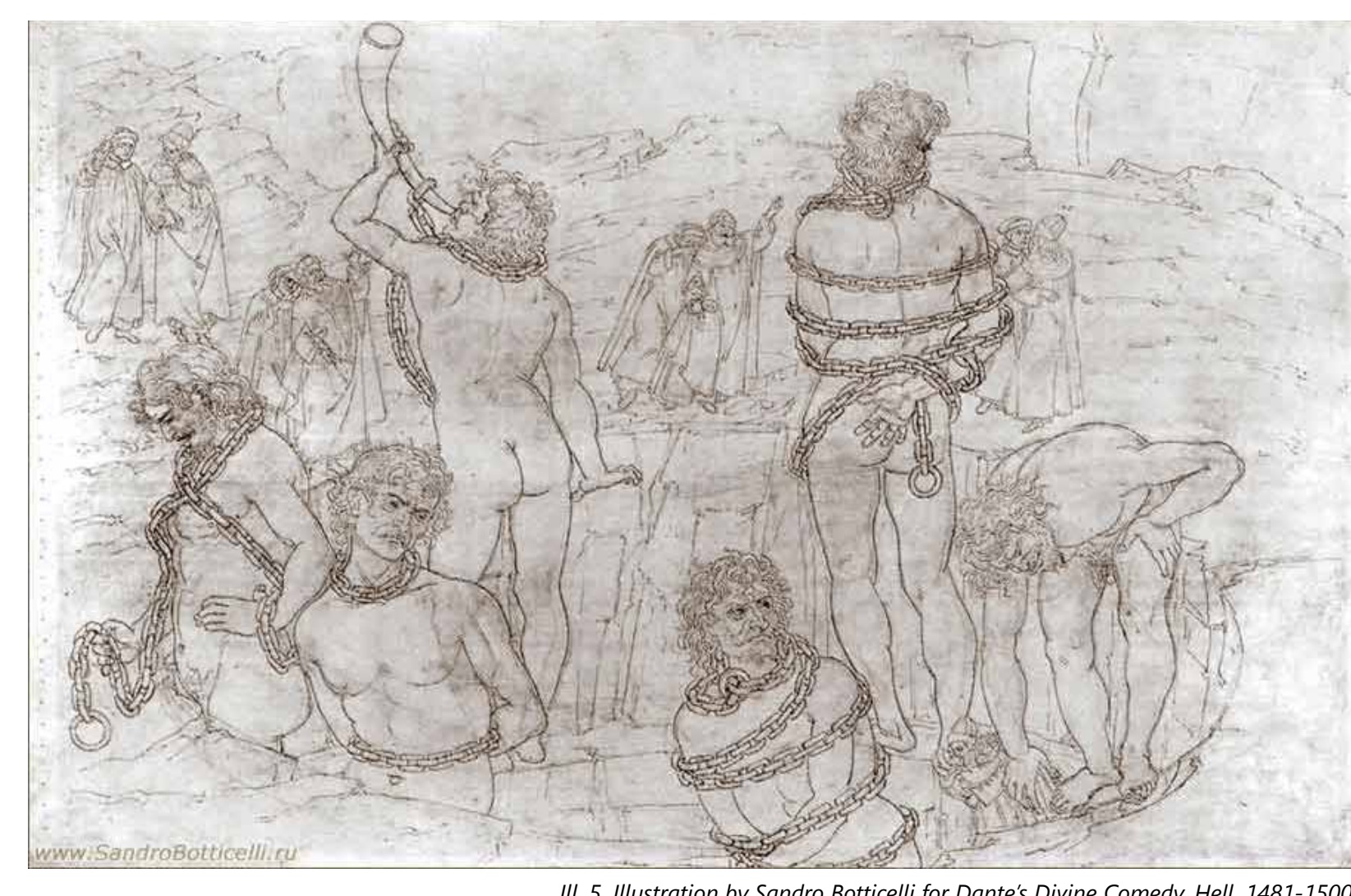

III. 5. Illustration by Sandro Botticelli for Dante's Divine Comedy. Hell. 1481-1500

ly constructed plans, who also has a dominant line that conveys the subtlest moods and emotional states of numerous characters. In a striking way, the very idea of this icon, where John the Theologian travels through the tiers (circles, spheres) of the Kingdom of Heaven and the earth of the Day of Judgment, brings to mind the creation of the great master of the Renaissance.

Moving from sphere to sphere and contemplating the phenomena of the transcendental world John the Theologian resembles Dante, led by Virgil or Beatrice, but the apostle's guides here are angels (or one of the apocalyptic elders), revealing to the apostle the mysteries of the Universe and the Eternal Kingdom of Heaven. The appearance in the icon of such characters as a black "demon" carrying infant souls in a box can only be understood as an echo of the ideas about Purgatory that sounded in Dante's poem. Next to this figure is the inscription "Both Death and Hell give up dead man's own". On the basis of this inscription, I. Kachalova identified the image as the personification of the Earth giving its dead ${ }^{52}$. But it is difficult to agree with this. The accompanying in-

52 Ikony Uspenskogo sobora Moskovskogo Kremlya. Vtoraya polovina XV-XVV Vek. Katalog. M.. Federal hoe gosudarstvennoe iko-kul'turnyj muzej-zapovednik «Moskovskij Kreml'», 2016. Cat.№ 4. P.129. (in Russian) scription is quite specific, and it deals with Death ing on the edge of the abyss, in which the rising dead and a girlish figure are depicted on a blue maiden figure is Death, and the figure we call the demon is the personification of Hell. It is remark able that in the lower corner of the icon, in accordance with the text of the Apocalypse, Hell, a dark figure with soft, feline grace is depicted leaving the confines of the underworld ${ }^{53}$. Thus, this is the first episode of the history of $\mathrm{Hell}$, and the dark figure with the box is the second episode represents the development of events. Now Hell raises a box filled with pure souls from the abyss, and the pose, and all the tectonics of his figure speaks of upward movement. Moreover, with his precious burden, he is heading towards the river beyond which the villages of the righteous stretch. Behind Hell is a fiery hell with sinners, and his fig ure is located on the border between Paradise and hell territory, exactly in the place where, since the end of the XV century, Russian icons of the "Last 53 Ikony Uspenskogo sobora Moskovskogo Kremlya. Vtoraya polow $\mathrm{XV}$-XVI vek. Katalog. M... Federal hoe gosudarstvennoe byudzhetnoe uchrezhdenie kul'tury «Gosudarstvennyj istorCat.№ 4. P.129. (in Russian). background. However, there is no inscription defining it as an allegory of the Sea. In this case, the
Judgment" began to depict a merciful fornicator ${ }^{54}$ Interestingly, there are two categories of dark forc es present on the icon. One is a traditional image of demons for ancient Russian art in the form of dark winged figures with thin arms and legs and hai standing on end, to which the master of the Apocalypse gave an extraordinary grace. However, in general, they are very traditional in their iconography ${ }^{55}$ Another category is those whom we conventionally called "demons". They differ sharply from ordinary demons, firstly, by the absence of wings, and secondly, by their completely Renaissance plasticity and grace, correctly articulated angles and comely hairstyles. The demon Hell, carrying souls in a box seems to sag slightly under his weight, leaning back and bending his knees, and the one depicted above, talking to an angel, is presented in the most difficult angle, with his back to the audience and halfturned to the angel. When looking at them, at how correctly and freely the figures are written, one involuntarily recalls Botticelli's illustration of "Hell" with the figure of a giant in chains standing with his back to the viewer. The master very accurately conveys the bending of the body, the transfer of body weight to one leg, the setting of the feet. He had clearly seen something similar to Botticelli's drawing, or maybe even had some kind of engraved sample. In general, in the figures of the "demons", of course, there is nothing left of the anatomical certainty with which the giant's body is conveyed by the Renaissance artist, but the masterly alignment of the angle with knowledge of chiasm is clearly present. The images of Botticelli and the images of John the Theologian traveling through the tiers of the icon, as in Dante's circles, are very close in spirit. These are very precisely found angles, gestures, facial expressions every time (despite the almost miniature size), conveying the nature of the conversation between the two philosophers. Twice the angel companion of John is depicted inside the sphere in which he moves through the space of the icon. John either looks at him or enters into this sphere. The idea of these images echoes those sheets of illustrations where Dante is depicted inside a sphere

54 Shalina I. A. Drevnejshaya pskovskaya ikona «Strashnogo suda» V sozvezdii L'va. Sbornik statej po drevnerusskom iskusstvu v chest' L'va Isaakovicha Lifshica ed. M. A. Orlova M.: Gosudarstvennyj institut iskusstvoznaniya, 2014. P. 538579. (in Russian).

55 Antonov D. I., Majzul's M. R. Demony i greshniki v drevnerusssian). with his escorts, floating in the space of Paradise gestures of raised hands expressing amazement delight, fear, reflection. Echoes of Renaissance art can be seen in a number of other motifs. So, the wonderful angels holding the figures of the winds evoke a Botticelli drawing depicting a beautiful Pomona leading by the hand of a naughty path, and the idea of the Wind as a blue figurine is the image of Zephyr in the famous Botticelli "Spring". The rarest iconographical motif, which we find in the icon "Apocalypse - a round dance of four figures of angels holding hands, vaguely resembles the round dance of angels in "Mystical Christmas", which Botticelli wrote in $1500^{56}$. Of course, all these are not direct, but indirect coincidences. But the similarity of some motives is very eloquent. The coincidences of the ideas and motives of the iconographic program of the "Apocalypse» with the main idea and some motives of Botticelli's illustrations to Dante's Divine Comedy that we have discovered are peculia manifestations of the influence of Renaissance art. We cannot yet say exactly which channels this influence went through, but it was there, the influence penetrated, assimilated and processed in accordance with the accepted system of icon painting ${ }^{57}$. The discovered parallels between the icon "Apocalypse" and Botticelli's illustrations of Dante make us inclined to date the icon from the Dormition $\mathrm{Ca}$ thedral no earlier than 1490-1500 years. Moreover given that the spread of new artistic ideas and images does not happen instantly, the icon painted in Moscow could have been created after 1500, but no later than the first decade of the XVI century. This work is undoubtedly a monument to a new period of understanding of eschatological ideas, which began after 1492. It was a kind of response of the Orthodox Church to the ideas of Chiliasm and a

56 The picture has an inscription in Greek "This picture I, Alexander, painted at the end of 1500 in the troubles of Italy in enth John and the second year of the Apocalypse will be fulfilled, at the time when the devil is three seconds half of the year was released. Then he was shackled in shackles in accordance with the twelfth and we will see him [trampled on the groundl as in this picture. " See: Dejmming B. Sandro Bot-

O nekotoryh kanalah proniknoveniya zapadnyh vliyanij.See
Chinyakova G.P. Drevnyaya Rus' i Zapad. Russkij licevoj Apokalipsis XVI-XVII vekov. Miniatyura, gravyura, ikona, stenopis'. M.: BuksMArt, 2017. P. C. 24. Preobrazhenskij A. S. Zapadnye motivy i formy v postvizantijskoj zhivopisi Moskovii. Predvaritel nye razmyshleniya. // Aktual'nye problemy teol harovoj, S. V. Mal'cevoj E YU. Stanyukovich-Denisovoj.-SPb. NP-Print, 2016.P. 252-266. (in Russian) 
special interest in the Revelation of John the Theologian, which arose in the West in connection with the Protestantism movement and, thus, is embedded not only in the Russian, but also in the Western cultural context. It is the icon "Apocalypse", painted for the DormitionCathedral, the main temple of the Moscow Kingdom, that stands at the origins

1. Alekseev, A.l. 2002. Pod znakom konca vremen: Ocherki russkoj religioznosti kon. XIV- nach. XVI v. Saint Petersburg, p. 347 (in Russian)

2. Alpatov, M.V. 1964. Pamyatnik drevnerusskoj zhivopisi $X V$ veka ikona «Apokalipsis» Uspenskogo sobora Moskovskogo Kremlya. Moscow, p. 110 (in Russian)

3. Antonov, D.I., Majzul's, M.R. 2011. Demony i greshniki $v$ drevnerusskoj ikonografii. Semiotika obraza, Moscow, p. 375 (in Russian)

4. Chinyakova, G.P. 2017. Drevnyaya Rus' i Zapad. Russkij licevoj Apokalipsis XVI-XVII vekov. Miniatyura, gravyura, ikona, stenopis'. Moscow, p. 374 (in Russian)

5. Dejmming, B. 2003. Sandro Bottichelli. Koln, p. 96 (in Russian)

6. Dionisij "zhivopisec preslovushchij". K 500-letiyu rospisi Dionisiya $v$ sobore Rozhdestva Bogorodicy Ferapontova monastyrya: Vystavka proizvedenij drevnerusskogo iskusstva XV-XVI wv iz sobranij muzeev i bibliotek Rossii Katalog. Moscow, 2002. p. 303 (in Russian)

7. Evseeva, L.M. 2000. Eskhatologiya 7000 goda i vozniknovenie vysokogo ikonostasa lkonostas. Proisk hozhdenie - Razvitie - Simvolika, Moscow, p. 411430 (in Russian)

8. Gordienko, E.A. 2001. Novgorod v XVI veke i ego duhovnaya zhizn', Saint Petersburg, p. 466 (in Russian) . duhony Uspenskogo sobora Moskovskogo Kremlya Vtoraya polovina XV-XVI vek. Katalog. M. Federal'no. Vtoradarstvenno byudzetn. Kat uch M.: Federal' noe gosuudarstvennyj istoriko-kul'turnyj muzej-zapovednudarstvennyj istoriko-kulturnyj muzej-zapovednik

. Kachava IYA 1990. Istoriya a hitektury Blagoverh-

chens chonsobork koj kul'tury, Moscow, pp.6-20. (in Russian)

11. Kachalova, I.YA. 1990. Monumental'naya zhivopis' Blagoveshchenskij sobor Moskovskogo Kremlya. K 500-letiyu unikal'nogo pamyatnika russkoj kul'tury. Moscow, pp. 21-44. (in Russian)

12. Kachalova, I.YA. 1999. Apokalipsis v stenopisi Blagoveshchenskogo sobora Blagoveshchenskij sobor Moskovskogo Kremlya: Materialy i issledovaniya ed. N. S. Vladimirskaya. Moscow, Gosudarstvennyj istoriko-kul'turnyj muzej-zapovednik "Moskovskij Kreml", pp. 30-53. (in Russian)

3. Kvlividze, N.V. 1998. Ikona "Blagoslovenno voinstvo Nebesnogo Carya" i ee literaturnye paralleli Iskusstvo hristianskogo mira, Moscow, vol.2, pp.49-56. (in Russian) of the Russian tradition of illustrating the Apocalypse in the XVI century. It can be assumed that the painting of the Annunciation Cathedral of the Moscow Kremlin in 1508 followed exactly this pattern as well as the frescoes on the theme of the Apoc alypse that decorated the narthex of the Assump tion Cathedral in 1513.
Татьяна Евгеньевна Самойлов кандидат искусствоведения старший научный сотрудник Государственная Третьяковская галерея

e-mail: tsamol@mail.ru Москва, Росси ORCID 0000-0003-0775-9127
14. Lifshic, L.I. 2005. O granice ponyatij "dionisievskij stil" ["stil' Dionisiya" Drevnerusskoe iskusstvo. Ideya i obraz Opyty izucheniy a vizantijskogo i drevnerusskogo iskusstva: Materialy Mezhdunarodnoj nauchnoj konferencii 1 - 2 noyabrya 2005 g., Moscow, pp.126-162. (in Russian)

5. Nevolin, YU.A. 1982. Novoe o kremlyovskih hudozhnikah miniatyuristah i sostave biblioteki Ivana Groznogo Sovetskie arhivy, no. 1, pp.68-70. (in Russian)

16. Nekrasov, A.I. 1937. Drevnerusskoe izobrazitel'noe iskusstvo, Moscow, p. 395 (in Russian)

17. Nersesyan, L.V. 1999. K voprosu o proiskhozhdenii i simvolicheskom soderzhanii "O Tebe raduetsya" Drevnerusskoe iskusstvo: Vizantiya i Drevnyaya Rus': 100-letiyu Andreya nikolaevicha Grabara (1896-1990), Saint Petersburg, pp.380-398. (in Russian)

18. Orlova, M.A. 1984. "Rozhdestvo" iz sobraniya P. D. Korina Drevnerusskoe iskusstvo. XIV-XV vv., Moscow, pp.253-266. (in Russian)

19. Popov, G.V. 1975. ZHivopis' i miniatyura Moskvy serediny XV- nachala XVI V. Moscow, p. 334 p. (in Russian)

20. Siničyna N.V.1998. Tretij Rim: istoki $i$ evolyuciya russkoj srednevekovoj koncepcii (XV-XVI VV), Moscow, 410 (in Russian)

21. Shalina, I.A. 2016. Novgorodskie ikonopiscy i "hitrecy" epohi vladyki Makariya Iskusstvo Velikogo Nongoroda. Epoha svyatitelya Makariya Katalog wystavki. Saint Petersburg., pp.5-162. (in Russian)

22 Shalina IA 2014. Drevnejshaya pskovskaya ikona Strashnogo suda $V$ sozvezdii L'va Sbonik ston po Strash IA. 2014 . Dreve sus shica, Moscow, pp.538-579. (in Russian)

23. Skrynnikov, R.G. 1991. Gosudarstvo icerkov' na Rusi XIVXVI w. Novosibirsk, Go 393 (in Russin)

24. Smirnova, E.S. 1998. Moskovskaya ikonopis' XIV-XVIII vekov, Leningrad, p. 318 (in Russian)

25. Smirnova, E.S. 2011. Iskusstvo knigi v srednevekovoj Rusi

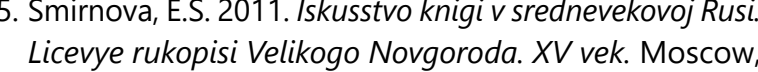
p. 559 (in Russian)

26. Samoylova, T.E. 2020. Blagoslovenno voinstvo Nebesnogo Carya. Moscow, p.68 (in Russian)

27. Sorokatyj, V.M. 1999. Ikona «Blagoslovenno voinstvo Nebesnogo Carya». Nekotorye aspekty soderzhaniya Drevnerusskoe iskusstvo. Vizantiya i Drevnyaya Rus'. 100-letiyu A. N. Grabara, Saint Petersburg, pp. 399417. (in Russian)

28. Zolotova, E. YU. 1986. ZHan Fuke. Moscow, p. 16 (in Russian)

DOI: 10.36340/2071-6818-2021-17-5-35-57

\section{ИКОНА «АПОКАЛИПСИС» ИЗ УСПЕНСКОГО СОБОРА КРЕМЛЯ. ДАТИРОВКА И ИСТОРИЧЕСКИЙ КОНТЕКСТ}

Аннотация: Икона «Апокалипсис» из Успенского собора Московского Кремля во многих отношениях остаёсся загадкой: у исследователей нет единого мнения по поводу её датировки, а, следовательно, нет контекста, в котором бы этот памятник занял своё прочное место.

На иконе много надписей. Все они соответствуют тексту Откровения Иоанна Богослова, которое на русский язык было переведено в конце XV века. В построении композиции мастер «Апокалипсиса» не мог опираться на византийскую традицию иллюстрирования Откровения, поскольку её фактически не было. Совпадения некоторых мотивов иконографической программы «Апокалипсиса» С мотивами иллюстраций Боттичелли к «Божественной Комедии», также как и роль

Икона «Апокалипсис» из Успенского собора давно находится в поле зрения исследователей, но по-прежнему во многих отношениях остаёт ся загадкой. У исследователей, обращавшихся к ней, нет единого мнения ни по поводу художественного центра, которому она принадлежит ни по поводу её датировки, а, следовательно, нет и контекста, в котором бы этот памятник занял своё прочное место.

Диапазон предлагаемых датировок - от 1480-х годов до начала XVI века - на первый взгляд не слишком широк, но в данном случае принципи ально попытаться понять, относится ли «Апокалипсис» к произведениям академической традиции конца XV века' или принадлежит уже иной пост-

1 Основная тенденция русской живописи конца XV - нача ла XVI в. - академическая. Она проявляется в стремлении кунификации и стандартизации форм, мотивов, приёмо го построения сцен, выработанных в живописи первой трети V в. Доведённые до идеального технического со- линии в обоих произведениях свидетельствуют о про й искусства Ренессанса в иконопис конца XV — начала XVI века. Обнаруженные параллел не позволяют датировать икону из Успенского собор ранее 1491-1500 годов. Учитывая, что распространение новых художественных идей и образов требует времени, икона, скорее всего, была написана после 1500 года в первом десятилетии XVI века и стала «знаменем» нового периода осмысления эсхатологических представле ний, связанных с предсказаниями западных астролого о всемирном потопе в 1524 году.

Ключевые слова: Икона, миниатюра, иконографическая программа, Апокалипсис, эсхатология, искусстео Ренессанса, влияния, искусство рисунка, традиция, иллюстрачии, иконографический мотие.

дионисиевской традиции, получившей развитие в первое десятилетие XVI века.

Второй важный вопрос - место этой иконы в развитии русской традиции иллюстрирования Откровения Иоанна Богослова в XV-XVI вв. Наиболее пристально изучением этой проблемь занималась И. Я. Качалова ${ }^{2}$. Она выстраивает целую цепочку произведений, созданных на тему Апокалипсиса. Исходной точкой развития традиции исследователь считает роспись Благовещен-

вершенства они превращаются в изобразительные формы, комбинации которых позволяли передавать смыс самых отвлечённых понятий. См.: Лифшиц Л.И. О границе понятий «дионисиевский стиль» и «стиль Дионисия ния византийского и древнерусского искусства: Материалы Международной научной конференции 1-2 ноября 2005 r. M., 2005. 130 c.

2 Качалова И.Я. Апокалипсис в стенописи Благовещенскопя: Материалыаовещенский собор Московского Кремская и др. М.: Государственный историко-куллтурный музей-заповедник «Московский Кремль», 1999. С. 30-53. 
ского собора Московского Кремля, созданную в 1405 году Феофаном Греком, содержавшую апо калиптические сюжеты ${ }^{3}$. Следующим памятни ком в этой цепочке И. Я. Качалова называет икону “Апокалипсис». Исследователь считает, что она была написана в 1480-е гг. специально для нового фиоровантиевского собора и, с точки зрения иконографии, восходит к росписи Феофана Грека, самому древнему примеру включения апокалиптических сюжетов в византийском искусстве. Далее следует роспись паперти Успенского со бора, появившаяся в 1515 году (паперть пере писана в XVII веке в соответствии с древними прорисями). Следующий после неё этап - роспись Благовещенского собора 1547 года ${ }^{4}$, программа которой, согласно исследованию И. Я. Качаловой, во многом основывается на иконографии иконь «Апокалипсис». Однако сама же И. Я. Качалова, настаивая на идее росписи Феофана Грека как исходной точке развития русской традиции, отмечает, что ввиду неразработанности темы Откровения в византийском искусстве, в неё могло быть включено лишь несколько избранных ви дений Иоанна Богослова ${ }^{5}$. С этой точки зрения трудно представить, что роспись 1405 года могла оказать существенное влияние на формирование сложной, многослойной и многоуровневой программы иконы «Апокалипсис». Уместно вспомнить и то, что в 1416 году Благовещенский собор был полностью перестроен. На его месте выросла иная значительно более обширная церковь, которую в свою очередь сменил храм 1489 года ${ }^{6}$. Этот собор, как мы помним, был расписан в 1508 году История кардинальных перестроек Благовещенского храма говорит о том, что память о росписи Феофана в ней могла быть сохранена лишь номинально, без какой-либо конкретики. О том, что собой представляла, с точки зрения программы

3 Качалова И. Я. Монументальная живопись // Благовещенский собор Московского Кремля. К 500-летию уникально4 В настоящее время Г. П. Чниякова опубликовала ещё одн памятник- рукописный Апокалипсис из собрания РГБ
(коллекция В. В. Егорова. Ф. 466. № 6), который она датирует 1540-ми годами. См. Чинякова Г.П. Древняя Русь и 3 пад. Русский лицевой Апокалипсис XVI-XVII веков.

Качалова И Я. Монументальная живогись // Благовещенский собор Московского Кремля. К 500-летию уникального памятника русской культуры. М.: Искусство, 1990. С. 30. Качалова И. Я. История архитектуры Благовещенского собора // Благовещенский собор Московского Кремл К 500 -летию уникального памятника русской культуры
М., 1990. С. 10.
ПСРЛ. Т. 13. Ч. 1. С. 9. роспись Благовещенского собора 1508 года, у нас также нет никаких сведений, кроме предположения о том, что роспись 1547 года, украсившая стены собора после печально знаменитого пожара, по устоявшейся традиции, могла в той или иной степени повторять предшествовавшую. Некоторые иконографические особенности ряда компо зиций, по наблюдениям И. Я. Качаловой, восходят к постдионисиевской эпохе ${ }^{8}$. А вот иконографи ческая программа росписи паперти Успенского собора 1515 года имеет прямое отношение к иконе, что прекрасно показала И. Я. Качалов в своей статье 9 . Таким образом, все приведённые выше факты указывают на то, что именно икона из Успенского собора стала родоначальницей той иконографической традиции, которая развивалась на протяжении XVI века. Предше ственницей её могла быть лишь гипотетически существовавшая, но не дошедшая до нас рукопись ${ }^{10}$. В данном контексте осмысление феноме на этого памятника как абсолютно новаторского, открывающего новую эпоху, обретает особую значимость.

Обратимся к живописному стилю иконы «Апокалипсис». Несмотря на то, что этот памятник относят К дионисиевской эпохе, его стиль разительно отличается от живописи знаменитого иконописца. Наиболее точное описание стиля Дионисия принадлежит Л. И. Лифшицу ${ }^{11}$. Он выделяет такие его значимые черты, как полное подчинение ритмического строя композиции плоскости, изысканный контурный рисунок, сильные ракурсы и удлинение пропорций в противовес уплощённости форм, полное отсутствие эффекта светотени и какого-либо драматического напряжения в ликах и фигурах, отсутствие связи жестов и движений с конкретным действием как приподнятост над всем мирским и житейским. Мастера эпохи наступившей после ухода с исторической сцен Дионисия, пытались следовать проторенной им

8 Качалова И. Я. Монументальная живопись // Благовещенго памятника русской культуры. М., 1990. С. 25-27.

Качалова И. Я. Апокалипсис в стенописи Благовещенского собора // Благовещенский собор Московского Кремля: зей-заповедник «Московский Кремль». Материалы и исследования. М., 1999. С. 30-53.

Чинякова Г.П. Древняя Русь и Запад. Русский лицевой Апокалипсис XV-XVI веков Миниатюра, гравюра, икона, сте-

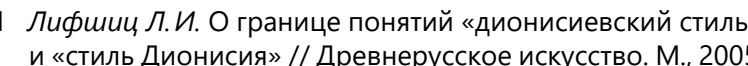
и « тропой, но высота его индивидуального стиля была недостижима. В работах его последователей черты стиля Дионисия объективизируются на основе академической традиции XV века, и на этом пути в искусстве снижается значение пространственных цезур и их ритма, фигуры постепенно отделяются от фона, а их жесты становятся бо лее реалистичными ${ }^{12}$. Если с этой точки зрения сравнить шедевр мастера «Апокалипсиса» с произведениями позднего Дионисия или постдионисиевского времени, то становится очевидным, что его стиль не укладывается ни в те, ни в другие рамки. Он абсолютно уникален, а по силе таланта, что отмечали многие исследователи, конгениален Дионисию ${ }^{13}$. Его искусство отличает неви данная ранее виртуозность и лёгкость рисунка, создаваемого свободной кистью опытного ми ниатюриста. Колорит его произведения почти акварельно прозрачен, и степень прозрачности такова что графическое начало в иконе звучит наравне с живописным, а подготовительный кистевой рисунок, просвечивающий сквозь прозрачно положенный колер, приобретает в стилистике иконы важнейшее формообразующее значение. Фигуры мастера «Апокалипсиса» столь же изящны, как и у Дионисия, они тоже имеют вытянутые пропорции, но их пластика, как и пространство, в котором они находятся, почти осязаемы. Каждое движение, каждый жест отличаются невиданной ранее пластической естественностью и конкретной наполненностью, а в построении архитектурных форм поражает как их пространственность, так и кристаллическая выверенность каждого компартимента. Особенно впечатляет изображение Небесного Иерусалима, города окружённого высокой стеной в каждом прясле которой в оконном проёме помещено изображение ангела. Мастер «Апокалипсиса» проявляет невероятное мастерство в построении многочисленных мизансцен, каждая из которых становится подлинным шедевром, будь то изображение ангела, с трудом сдерживающего фигурку Ветра изображённого подобно расшалившемуся пут ти, или самого Иоанна Богослова, ведущего философскую беседу со старцем в белых одеждах или битва ангелов-всадников с силами зла. Ком-

12 Лифшии Л.И. О границе понятий «дионисиевский стиль»
исстиль Дионисия»// Древнерусское искусство. М. 2005. и «стиль Дио

13 Лифшиц Л.И. О границе понятий «дионисиевский стиль»

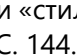

позиция иконы включает в себя множество сцен и фигур, но при этом не проигрывает в цельности, и, по общему мнению всех писавших о ней исследователей, являет собой «светлый образ грядущего блаженства», изображая не столько ужасы последнего акта мировой истории, сколь ко радость и славу, обретаемых праведниками

Вся драма Апокалипсиса представлена в трёх актах — трёх грандиозных картинах, расположенных тремя ярусами. В верхнем мы видим Небо небес - в трёх рядоположенных круглых славах представлены Господь Саваоф, Агнец и Христос-Вседержитель, над которыми ангель распростёрли свиток Нового Неба. Композици онным центром среднего яруса является Слава с Христом-Еммануилом. В этом ярусе представлены самые драматические моменты вселенской битвы добра и зла. Здесь мы видим Вавилонскую блудницу, рушащиеся города, ангелов, собирающих страшную жатву, апокалиптических зверей пожирающих народы.

Третий, нижний ярус являет картину тор жества совершающегося справедливого Суда со Христом-Еммануилом в центре. От основания Его трона в сторону Небесного Иерусалима течёт река Жизни, а по её сторонам располагаются праведники и грешники. Несмотря на наличие трёх выраженных регистров композиции границы между ними условны. В картину каждого яруса вставлены такие мизансцены, дей ствие которых развивается с переходом из яруса в ярус и ясно указывает на их проницаемость. Так, в верхнем регистре апокалиптические всадники скачут по дуге мандорлы Христа из второго яруса, а ангельское воинство, низвергает с Неба падших ангелов, от которых во второй регистр, на землю течёт кровавый поток с падающими звёздами. И наоборот, из второго регистра вверх стремится спасающаяся от дракона Жена, об лачённая в солнце, и в верхнем ярусе мы видим её уже в белых одеждах, восседающей на пре столе, утверждённом под Славой Христа-Вседержителя. Важнейшим композиционным приёмом мастера является присутствие во всех ярусах многократно повторенной фигуры testis'a, свидетеля, своеобразного лирического героя, а именно самого Иоанна Богослова, глазами которого мы созерцаем все представленные сцены, путешествуя 14 Иконы Успенского собора Московского Кремля. Вторая (автор описания И. Я. Качалова) 
С ним из яруса в ярус. Сначала ангел передаёт Иоанну книгу Откровения, полученную из рук Самого Христа, и апостол отправляется в мисти ческое путешествие по иконе. Мы видим Иоанна на Небе, ведущего беседу со старцем, открыва ющим ему картину славы Христа Вседержителя. Мы видим, как ангел показывает Иоанну Жену, спасшуюся от дракона и сидящую на престоле в селениях Христа. В среднем ярусе Ангел проводит апостола посреди всех апокалиптических ужасов земной драмы и направляет вверх, указывая на Жену, облачённую в солнце, убегающую от дракона. В нижнем регистре Иоанн изображён дважды. В первом с Ангелом он идёт вдоль реки Жизни, во втором - Ангел и Иоанн стоя под стенами Небесного Иерусалима и взирают на сидящих посреди него праведников в белых одеждах. Замечательно, что среди праведников выделены два молодых персонажа в характерных русских княжеских шапках - Борис и Глеб, представители русской святости среди святости вселенской. На иконе довольно много надписей, и в основном они соответствуют тексту Откровения Иоанна Богослова ${ }^{15}$.

История изучения иконы довольно подробно изложена в Каталоге икон Успенского собора 2017 года ${ }^{16}$. И. Я. Качалова привела здесь все выдвигавшиеся разными авторами датировки но остановилась на дате, которую предложил Л. И. Лифшиц - 1480-е годы, полагая, что икона была написана для только что (1479) выстроенного Успенского собора. С этим мнением согласуется и датировка, выдвинутая Э. С. Смирновой. Однако в подборе аналогий у этих исследова телей нет единого мнения. Так, Э. С. Смирнова сблизила стиль мастера «Апокалипсиса» со стилем миниатюр Книги пророков, датированной 1489 годом 17, тогда как Л. И. Лифшиц считает, что миниатюры Книги пророков лишены той эллинской грации, которой дышат образы иконь «Апокалипсис», и в них резче проявляются черты графической стилизации пластической формь В качестве аналогии «Апокалипсису» исследователь привел миниатюры рукописи новгородского

15 Иконы Успенского собора Московского Кремля. Вторая половина XV - XVI век: Каталог. М., 2016. Кат. № 4. С. 13 (автор описания И. Я. Качалова).

16 Иконы Успенского собора Московского Кремля. Вторая половина XV—XVI век: Каталог. М., 2016. Кат. № 4. С. $120-$
134 (автор описания И. Я. Качалова). 1988. С. 36, 296-297. происхождения - а именно, «Апостола» (ГИМ), датированного рубежом 70-80-х годов XV в., подчеркивая, что мастер, написавший миниатюр ком Дионисия ${ }^{18}$. Однако сравнение миниатюр «Апостола» и иконы, как нам представляется, показывает, что стиль мастера «Апокалипсиса» значительно дальше ушёл от них как в эллинской грации, так и в виртуозности владения линией. Г.В.Попов склоняется к несколько более поздней датировке «Апокалипсиса»-около 1500 года ${ }^{19}$ Аналогии, которые он приводит, относятся к началу XVI века: миниатюры Псалтири с восследованием 1502 года из Иосифо-Волоцкого монастыр (ГИМ. Епарх. 81), Лествицы Иоанна Синайского начала XVI века. из Троице-Сергиевой Лавры (РГБ, ф. 304. № 162) ${ }^{20}$ и сборник с лицевыми текстами «Хождения Иоанна Богослова» и «Жития Бориса и Глеба» последней четверти XV начала XVI века (СПб.: ИИРАН, Архив. Колл. 238 Оп. 1. № 71) ${ }^{21}$. Наиболее близки иконе «Апокалипсис», на наш взгляд, миниатюры последней рукописи, в которой высокие тонкие фигуры написаны свободной кистью и лишь слегка тонированы жидко положенной краской. Заметим, что началом 1500-х годов датировал икону «Апокалипсис» и М. Алпатов, один из самых первых её исследователей ${ }^{22}$. Г. П. Чинякова, исследователь иконографической традиции иллюстрирования Апокалипсиса, считает, что икона могла быть создана после 1500 года 23.

Несмотря на разнящиеся датировки, все исследователи сходятся в том, что икона «Апокалипсис положила начало иному, отличному от диониси евского, стилевому направлению. Тем не менее проблема генезиса стиля мастера «Апокалипсиса остаётся нераскрытой. Если в случае с Дионисием, 8 Лифшиц Л.И. О границе понятий «дионисиевский стиль и «стиль Дионисия» // Древнерусское искусство. М., 2005

99 Попов Г.В. Живопись и миниатюра Москвы середины XV20 Дионисий «живописец пресловущий». К 500-летию росписи Дионисия в соборе Рождества Богородицы Ферапонтова монастыря. М., 2002. Кат. № 65 (автор описания

И. В. Левочкин).
Диноисий «жвописец пресловущий». К 500-летию ро понтова монастыря. М. 2002. Кат. № 67 (автор описания Г. А. Победимова).

22 Алпатов М. B. Памятник древнерусской живописи XV век икона «Апокалипсис» Успенского собора Московского Кремля. М., 1964

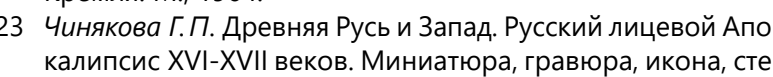
нопись. М., 2017. С. 24. несмотря на всю индивидуальность стиля мастера, очевидна его генетическая связь с искусством Андрея Рублёва, то откуда пришло искусство мастера «Апокалипсисаш, не совсем ясно. М. Алпатов считал, что он принадлежит московской культуре, но видел в нём и влияние Новгорода. Какие же черты искусства мастера «Апокалипсиса» можно назвать новгородскими? Все исследователи сходятся в том, что это главенство линии подробнейшим образом выстраивающей форму, которая не укрывается цветом. В Новгороде конца XV и раннего XVI века подобный графический стиль проявился прежде всего в искусстве миниатюры (Лествица Иоанна Лествичника со Словами Кассиана Римланина и отшельнй ФиЛимона (Погодинская Лествица), РНБ, Погод. 1058-1480-е гг.; Апостол (Лихачёвский Апостол), Институт исто рии РАН. Архив, колл. 238. Оп. 1, 3274, 1490-е начало 1500-х годов) ${ }^{24}$. Эти рукописи вышли из скриптория новгородского архиепископско го дома, который развивался в конце XV века под руководством архиепископа Геннадия, а затем после 1523 года - под эгидой архиепископа Макария. Заметим, что и архиепископ Геннадий и Макарий были ставленниками Москвы, «агентами самодержавной власти», как писал о них А. И. Некрасов ${ }^{25}$. В новгородском скриптории тогда трудились бок о бок и московские мастера приехавшие вместе с архиепископом, и местные новгородские, оказывая влияние друг на друга ${ }^{26}$. Как мы видим на примере Книги пророков, графический стиль был не чужд и московскому искусству ${ }^{27}$. Любопытно, что большинство рукописей этого времени атрибутируются как новгород ские или московские по месту вложения книги, но этот принцип атрибуции не всегда работает

24 Смирнова Э.С. Искусство книги в средневековой Руси. Лицевые рукописи Великого Новгорода. XV век. М., 2011. Кат

25 Некрасов А.И. Древнерусское изобразительное искусство

26 Смирнова э.С. Искусство книги в средневековой Руси. Лицевые рукописи Великого Новгорода. XV век. М., 2011 С. 142-144, 159. Гордиенко э. А. Новгород в XVI веке и его Суховная жизнь. СТб., 2001. С. .4-48. Скрынников Р.Г. Госу-

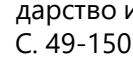

27 Графический стиль в памятниках московской традиции М. А. Орлова считает столичным памятником икону «Рождество» из собрания П. Корина конца XV века, которую М. Алпатов приводил в качестве близкой аналогии иконе “Апокалипсис». См.: Орлова М.А. «Рождество» из собра ния П. Д. Корина // поскольку рукопись могла принадлежать кисти новгородского, так и московского мастера. Новгородский скрипторий на рубеже XV переводами Библии, Откровения Иоанна Богослова и других сочинений наряду с русскими книжниками трудились и переводчики, приехавшие из разных земель, в том числе и из западных, как, например, монах-доминиканец Вениамин ${ }^{28}$. Мь имеем все основания предполагать, что здесь могли работать и приглашённые мастера-мини атюристы западной выучки. Особая творческая атмосфера, царившая в скриптории, позволяла мастерам учиться друг у друга. Не случайно М. Алпатов в связи с иконой «Апокалипсис» говорил о московском мастере, испытавшем влияние Новгорода, но при этом не отрицал и возможности влияния Москвы на Новгород ${ }^{29}$. Через искусство книжной миниатюры московская школа действи тельно оказала на Новгород огромное влияние смягчив резкий энергичный стиль новгородской традиции, сделав его более рафинированным. Это направление продолжало развиваться в Новгороде и в эпоху Макария преобразовалось в так называемую макарьевскую школу. Её ярким при мером в миниатюре может служить «Житие Ни фонта» (ГИМ, 30-е годы XVI в.), в котором, кстати А. И. Некрасов также усматривал западные влияния ${ }^{30}$. Таким образом, вполне вероятно, что “рафический стиль» изначально был всё-таки явлением московским, но именно в Новгороде он нашёл благодатную почву для своего дальнейшего развития, и мы не можем исключать, что принадлежащий московской культуре мастер «Апокалипсиса», стиль письма которого обличает опытного миниатюриста, был связан со скрипторием новгородского архиепископского дома.

Мысль о воздействии западных гравюр на миниатюру грозненского времени уже прочно ут вердилась в науке ${ }^{31}$. А вот западные влияния в живописи начала XVI века - проблема менее разработанная, $x$ дом исследователей. Присутствие ренессансных 28 Гордиенко Э.А. Новгород в XVI веке и его духовная жизнь

Алпатов М. В. Памятник древнерусской живописи XV века
икона «Апокалипсис» Успенского собора Московского Кремля. М., 1964. С. 104

зо Некрасов А.И. Древнерусское изобразительное искусство

Неволин Ю.А. Новое о кремлёвских художниках-минидские архивы. 1982. № 1. С. 68-70. 
черт М. Алпатов видел в иконе «Апокалипсис» ${ }^{32}$. Они проявились прежде всего в невероятной пластической свободе всех персонажей, а также в особом внимании к мельчайшим деталям, к мимике и жестам, переданным с редкой достоверностью и убедительностью. Можем ли мы предположить, что графическая манера мастера также связана с влиянием западного искусства? Хорошо известно, что рисунку в эпоху Ренессанса отводили важное место в системе обучения живописи, и значимость наброска, рисунка в этот период вырастает до его осмысле ния как почти самостоятельного произведения. В данном контексте уместно вспомнить слегка подцвеченные рисунки Жана Фуке, служившие подготовительным этапом для создания жи вописных портретов (расцвет творчества этого французского мастера пришёлся на вторую половину XV века) ${ }^{33}$. Не исключено, что появление в русском искусстве конца XV - нача ла XVI века таких живописных произведений где превалирует графическое начало (Книга пророков, Житие Бориса и Глеба) ${ }^{34}$, явилось своеобразным русским ответом на общеевропейскую тенденцию развития рисунка как самостоятельного вида искусства. Интересно, что в знаменитом Погодинском Евангелии (РНБ) ми ниатюры с изображением евангелистов написаны в классическом для постдионисиевской эпохи стиле - это прекрасная многослойная сложная живопись. А вот символы евангели стов (орёл, лев, ангел, телец), помещаемые как навершие заставок византийского стиля, напи саны совершенно иначе ${ }^{35}$. В них главенствуе линия, которая просвечивает сквозь прозрачно положенную краску, подцветку. Эти миниатюр ные образы отличаются и по духу от «портре тов» евангелистов. У них харАктерные жесты, мимика, в них нет лирической идеализации, в них явственно чувствуется иное, не византийское начало. Такое впечатление, что неиз вестный нам мастер, играючи, как бы между

32 Памятник древнерусской живописи XV века икона «Апокалипсисљ Успенского собора Московского Кремля. М
1964. С. 79-80. 33 Золооова Е. Ю. Жан Фуке. М.: Изобразительное искусство,
1986.
34 Дионисий «живописец пресловущий». К $500-$ летию ро-

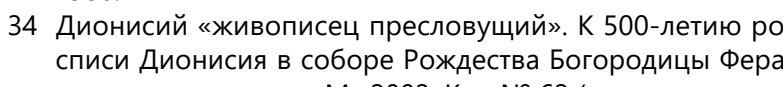
понтова монастыря. М., 2002. Кат. № 62 (автор описания И. В. Левочкин), Кат. № 67 (автор описания Г. А. Победи-
РНБ. Погод. 133. Л. 10 об. Л. 12. Л. 173. Л. 110. Л. 273. прочим, дополнил строгую архитектуру заставок своими почти небрежными, но мастерски очными в каждой детали рисунками. И по стилю, и по технике исполнения эти миниатюрные изображения символов евангелистов сопоставимы с иконой «Апокалипсис» из Успенского собора и могут служить ей близкой, хотя и не совсем точной аналогией. Безусловно, маэстрия автора «Апокалипсиса» остаётся недостижимой высотой, но данная аналогия, как и аналогии, приведённые Г. В. Поповым, позволяют как нам кажется, вернуться к обсуждению проблемы датировки «Апокалипсиса» из Успенского собора началом XVI века.

Апокалиптические настроения, как известно, окрасили последние годы правления Ивана III, когда общество жило ожиданием конца света, назначенного на 1492 год ${ }^{36}$. Ответом эпохи на предчувствия конца света в искусстве 80-90-х годов XV века было, во-первых, завершение формирования высокого иконостаса с иконой Спа са в силах как центрального образа деисусного чина, а во-вторых, насыщение новыми мотивам традиционной иконографии «Страшного суда» ${ }^{37}$. Но, пожалуй, самым ярким явлением времени стало рождение новой иконографии, получившей название «О Тебе радуется». В ней один из мотивов композиции «Страшный суд» был трансформи рован в образ Небесного Иерусалима ${ }^{38}$. Заметим, что все эти произведения не были связаны текстуально с Откровением Иоанна Богослова хотя текст Апокалипсиса был известен древне русским книжникам. Однако в дошедших до нас древних рукописях он всегда сопряжён с толкованиями Андрея Кесарийского. Наиболее ранний образец полного текста Апокалипсиса без толкований на церковно-славянском языке содержит московский кодекс Нового Завета из Чу дова монастыря, датируемый второй половиной XIV века. Г. И. Вздорнов считает, что данная рукопись, написанная в Константинополе, появилась на Руси в конце XIV века, но не получила 36 Алексеев А. И. Под знаком конца времен: Очерки рус. ре-
лигиозности кон. XIV - нач. XVI вв. СПб: 2002 лигиозности кон. XIV - нач. XVI вв. СПб., 2002. Евсеева Л. М. Эсхатология 7000 года и возникновение на И.А. Древнейшая псковская икона «Страшного суда // В созвездии Льва. Сборник статей по древнерусскому искусству в честь Льва Исааковича Лифшица. М., 2014

38 Нерсесян Л.В. К вопросу о происхождении и символическом содержании «О Тебе радуется» // Древнерусское ис-
кусство: Византия и Древняя Русь: К 100-летию Андрея Николаевича Грабара (1896-1990). СПб., С. 394. широкого отклика ${ }^{39}$ В 1499 году полный текст Откровения был включён в Библию архиепископа Геннадия ${ }^{40}$. Столь знаковое событие вряд ли могло остаться незамеченным в мире книжности и книжников, и в этом контексте знаменательно, что икона из Успенского собора - первое произведение иконописи, содержащее развёр нутые надписи, цитирующие Откровение Иоанна Богослова.

Мастер «Апокалипсиса» не мог опираться на византийскую традицию иллюстрирования Откровения, поскольку её фактически не было. Апокалиптическая серия гравюр Альбрехта Дюрера появилась в 1496-1498 годах, и, как мы знаем, влияние иконографии Дюрера проявилось впервые в русском искусстве только в середи не XVI века во фресках Благовещенского собора (изображение ангела на огненных ногах) ${ }^{41}$. От личается интерпретация текста мастером Апокалипсиса и от более ранней западной традиции известной нам по таким памятникам, как Трирский и Бамбергский Апокалипсис ${ }^{42}$. С точки зрения сюжетного состава икона из Успенского собора значительно ближе к гобеленам Анжерского Апокалипсиса 1373-1381 годов ${ }^{43}$. По крайней мере обращает на себя внимание изображение в верхнем ярусе иконы наряду с Саваофом и Христом Вседержителем Агнца в окружении старцев, что является, безусловно, данью западной традиции. Так чем же мог вдохновляться автор иконографии московского Апокалипсиса?

После того как в 1492 году запланированный конец света не состоялся, общество не рассталось с апокалиптическими настроениями, но они стали развиваться в несколько ином русле. В 1499 году немецкий математик Штофлер опубликовал своё новое предсказание о всемирном потопе, который он назначил на 1524 год. Его опубликованные предсказания быстро распространились не только

39 Вздорнов Г.И. Роль славянских монастырских мастерских письма Константинополя и Афона в развитии книгописания и художественного оформления русских рукописей на рубеже XIV-XV вв. // ТОДРЛ. Отв. ред.: А. С. Лихачев Л., 1968. Т. 23. С. $176(171-199)$.

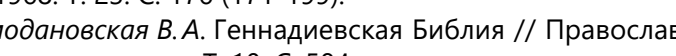
T. 10. C. 584

го собора // Благовещенский собор Московского Кремля. Материалы и исследования. М., 1999. С. 41-42.

42 зорич А. Апокалипсисы IX-XI вв. // https://www. medievalmuseum.ru/01mss/medieval_codexes_apocalipsi. GiraudRennes, 1982 по Европе, но проникли и в Россию. Их популяри зации на Руси способствовал «немчин» Николай Булев. Уроженец Любека, получивший университетское образование, Николай Булев первый раз оказался в России в составе посольства Георга фон Турна в 1490 году и задержался на некоторое время в Новгороде, так как получил от архи епископа Геннадия заказ на составление новых пасхальных таблиц. В самом начале XVI века (после 1504 года) Булев оказался при папском дворе а в 1508 году вновь в России, где стал придвор ным врачом великого князя. В своих сочинени ях он пропагандировал не только астрологию, но и доказывал преимущество католического дог мата o Filioque, выступив катализатором развития русской богословской мысли. Православным книжникам пришлось вступить в полемику с этим представителем западного мира ${ }^{44}$. Одним из самых ранних русских произведений на тему конца света стало «Сказание о седьмой тысяче лет» Иосифа Волоцкого, где он убеждает своих читателей в том, что последние сроки известны только Самому Божественному Сыну и не открыты ни апостолам, ни даже ангелам ${ }^{45}$. В своём сочи нении Иосиф неоднократно ссылается на Откро вение Иоанна Богослова, но не приводит прямых цитат. Знамя Иосифа было подхвачено другими книжниками. Своеобразным итогом этой работы явилось знаменитое Послание старца Филофея к Мисюрю-Мунехину (1524), где, продолжая полемику с Булевым, он создал картину упорядоченного Божественной волей космоса, прочного и неизменного, подчинённого не движению звёзд а планам божественного домостроительства ${ }^{4}$. Таким образом, пик интереса к теме конца света приходится именно на период с конца XV века до 1524 года. Именно в этот период в русском искусстве появляется целый ряд образов «Иоанна Богослова на Патмосе», на которых он представ лен диктующим Откровение, данное свыше свое му ученику Прохору. Это иконы «Апостол Иоанн

44 Буланин Д. М. Булев (Бюлов) Николай // Словарь книжников и книжности Древней Руси. В. 2. 2-я половина XIV-XVI 4. 1. Л., 1988. Синицына Н. В. Третий Рим: истоки и эволюция русской срен лоцкого // вцИ. 2008. № 2 (10). С. 121-220. Автор датирует создание «Просветителя» 1490-1502 годами. Это тоже важный факт для датировки нашей иконы, так как Иоси Волоцкий был тлавым идеологом эпохи, его произве 46 Синицына Н.В. Третий Рим: истоки и эволюция русской 
Богослов на Патмосе с хождением» из Дмитрова (ЦМиАР) конца XV века ${ }^{47}$, одноимённые иконь начала XVI века из Троицкой церкви (ГТГ), из коллекции И. С. Остроухова (ГТГ) ${ }^{48}$, из вологодской церкви на Тошне (ВГИАМЗ) ${ }^{49}$. Икона «Апокалип сис» из Успенского собора естественно ложится в этот контекст особого интереса к апокалиптиче ской теме, но при этом представляет собой глубоко своеобычный, ни на что не похожий ответ на вызов эпохи. В этом произведении был создан не образ планетарного разрушения и устраше ния, но образ нерушимого Божественного космоса и победы над хаосом.

Начавшийся в царствование Ивана III процесс проникновения в русскую культуру ренессансных влияний достигает своего апогея именно в нача ле XVI века, в последние годы правления Ивана Васильевича и первые годы царствования его сына Василия III. Присутствие Николая Булева при великокняжеском дворе в 1508 году говорит само за себя. Булев, как мы помним, в 1480-е годы находился при папском дворе в Риме, крупней шем наряду с Флоренцией центре ренессансной культуры, где в 1480-1481 годах по приглаше нию папы Сикста работали лучшие мастера Италии, в числе которых был, например, Сандро Боттичелли. Эти факты важны для нас, поскольку подтверждают существование каналов, че рез которые могли проникать на Русь влияния итальянского искусства. В 1490-е годы в Италии возвышает свой голос Савонарола, призывая к покаянию. В ожидании наступления конца времён под воздействие этого проповедника попадают многие художники эпохи Ренессан са, отказываясь от ценностей гуманистической культуры и обращая свой взор к Церкви. Одним из них был Боттичелли. В этот период он создаёт одно из своих самых значимых и новаторских произведений - иллюстрации к «Божествен ной комедии» Данте (1492-1500), исполненные в новой графической технике (металлический штифт, перо). Боттичелли обращался к иллюстрированию Данте и ранее, в 1481 году. Тог-

47 Центральный музей древнерусской культуры и искусства сост. Л. М. Евсеева, В. М. Сорокатый. Москва, 2007. Кат.

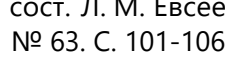

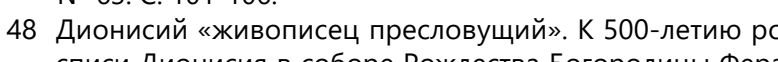
списи Дионисия в соборе Рождества Богородицы Фера

понтова монастыря. М., 2002. Кат. № 48. Автор описания
Э. К. Гусева. С. 191.
49 Иконы Вологды XIV-XVI веков. М., 2007. Кат. № 35. С. 271-

Иконы Вологды XIV-XVI веков. М.,
281. Автор описания Л. В. Нерсесян. да по его рисункам к «Аду» были выполнены гравюры для типографского издания ${ }^{50}$. Рисунки Боттичелли к «Божественной комедии» по своС̆ стилистике отличаются от его ранних, классических ренессансных произведений. Главное чо отмечают исследователи - отсутствие характерного для эпохи Возрождения математически обоснованного перспективного построения. Трёхмерность в них передаётся прежде всего соединением графических планов и ракурсами фигур. В его рисунках мы видим незамкнутое движение циркульных линий, изображения сфер «с почти имматериальными очертания ми» ${ }^{51}$. Они явно свидетельствуют о том, что по воздействием новой религиозной волны искусство ренессансного мастера изменилось и стало более иррациональным. Легко представить, что оно могло бы найти живой отклик среди мастеров, остающихся в старой, средневековой системе, таких как мастер «Апокалипсиса» из Успенского собора, который также трёхмер ность передаёт прежде всего ракурсами фигур и соединением графически выстроенных планов у которого также главенствует линия, переда ющая тончайшие настроения и эмоциональные состояния многочисленных персонажей. Пораз ительным образом и сама идея этой иконы, где Иоанн Богослов путешествует по ярусам (кругам сферам) Царства Небесного и земли Судного дня, заставляет вспомнить творение великого мастера эпохи Возрождения. Перемещающийся из сферь в сферу и созерцающий явления трансцендентного мира Иоанн Богослов напоминает Данте ведомого Вергилием или Беатриче, но прово дниками апостола здесь являются ангелы (или один из апокалиптических старцев), открывающие апостолу тайны мироздания и вечного Царства Небесного. Появление в иконе таких персонажей иконы, как чёрный «демон», несущий в коробе младенческие души, может быть понято только как отзвук представлений о Чи

50 https://www.britannica.com/biography/Sandro-Botticelli/

\section{Late-works}

Frank Zöllner Sandro Botticelli als Apelles und als
Grisaillemaler. Petronius' Monocremos" als Inspiration für die Selbstreferentialität der Malerei?: Kunst und Theorie des Helldunkels $1300-1550$ // Chiaroscuro als ästhetisches Prinzip. Kunst und Theorie des Helldunkels 1300-1550, ed. by Claudia Lehmann, Norberto Gramaccini, Johannes Rößler and Thoma Dittelbach, Berlin, New York et. al:: de Gruyter, 2018. Herbert
Horne, Botticelli: Painter of Florence.Florenz: S.P. S. 1986. http://www.binetti.ru/content/1047 с этой фигурой располагается надпись «И Смерть и Ад даша мертвеца своя». На основании этой надписи И. Я. Качалова определила изображе ние как олицетворение Земли, отдающей своих мертвецов ${ }^{52}$. Однако с этим трудно согласиться. Сопроводительная надпись достаточно конкретна, и в ней речь идёт о Смерти и Аде. Фигу ра «демона» с коробом стоит на краю бездны, в которой на голубом фоне изображены восстающие мертвецы и девическая фигура. Однако надписи, определяющей её как аллегорию Моря нет. В данном случае девическая фигура - это Смерть, а фигура, которую мы называем демоном - персонификация Ада. Замечательно, что в нижнем углу иконы в соо. Апокалипсиса Ад в виде тёмной фигуры с мягкой, кошачьей грацией изображён покидающим пределы преисподней ${ }^{53}$. Таким образом, это первый эпизод истории Ада, а тёмная фигура с коробом - это второй эпизод, развитие событий. Теперь Ад поднимает из бездны короб, наполненный чистыми душами, причём поза и вся тектоника его фигуры говорит о движе нии вверх. Более того, со своей драгоценной ношей он направляется в сторону реки, за которой простираются селения праведников. За спиной Ада - огненная геенна с грешниками, а его фи гура расположена на пограничной между Раем и геенной территории, именно в том месте, где с конца XV века на русских иконах «Страшного суда» стали изображать милосердного блуд ника ${ }^{54}$. Интересно, что на иконе присутствуют тёмные силы двух категорий. Одна - это тради ционное для древнерусского искусства изобра жение бесов в виде тёмных крылатых фигурок с тонкими ручками и ножками и торчащими дыбом волосами, которым мастер Апокалипси са придал необыкновенное изящество. Однако в целом они весьма традиционны по своей иконографии ${ }^{55}$. Другая категория - это те, кого мы

52 Иконы Успенского собора Московского Кремля. Вторая половина XV - XVI век. Каталог. М., 2016. Кат. № 4. С. 129 (автор описания И. Я. Качалова).

53 Иконы Успенского собора Московского Кремля. Вторая

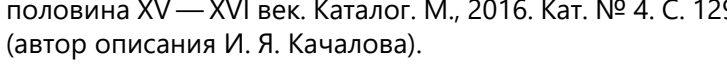
54 Шалина И. А. Древнейшая псковская икона «Страшного суда» // В созвездии Льва. Сборник статей по древнерусред. М. А. Орлова. М.: Государственный институт искус Свознания, 2014. С. 5з8-5у9.

5 Антонов Д.И., Майзульс М.Р. Демоны и грешники в древ- условно называли «демонами». Они резко от личаются от обычных бесов, во-первых, отсут ствием крыльев, а во-вторых, своей совершенно ренессансной пластикой и грацией, правильно артикулированными ракурсами и благообразными причёсками. Демон Ад, несущий души в коробе, как бы слегка проседает под его тяжестью, откидываясь назад и подгибая коле ни, а тот, что изображён вверху беседующим с ангелом, представлен в сложнейшем ракурсе спиной к зрителям и вполоборота к ангелу. При взгляде на них, на то, как правильно и свободно написаны фигуры, невольно вспоминается иллюстрация Боттичелли к «Аду» с фигурой гиганта в цепях, стоящего спиной к зрителю. Мастер очень точно передаёт изгиб тела, перенос яяести тела на одну ногу, постановку стоп. Он явно видел нечто подобное рисунку Боттичел ли, а может, даже имел какой-то гравированный образец. В целом, в фигурах «демонов», разусеется, не остается ничего от той анатомической определённости, с которой передано тело гиганта у ренессансного художника, но мАстер ская выстроенность ракурса со знанием хиазм явно присутствует. Очень близки по духу образам Боттичелли и изображения Иоанна Богослова, путешествующего по ярусам иконы, как по Дантовым кругам. Это каждый раз очень точ но найденные ракурсы, жесты, мимика (несмотря на почти миниатюрный размер), передающие характер беседы двух философов. Дважды ангел-спутник Иоанна изображён внутри сферы, в которой он перемещается по пространству иконы. Иоанн либо взирает на него, либо входит внутрь этой сферы. Идея этих образов перекликается с теми листами иллюстраций, где Данте изображается внутри сферы со своими провожатыми, парящими в пространстве Рая жестами воздетых рук выражая изумление, восторг, страх, размышление. Переклички с искусством Ренессанса можно увидеть и ещё в целом ряде других мотивов. Так, замечательные анге лы, удерживающие фигурки ветров, вызывают в памяти рисунок Боттичелли, изображающий прекрасную Помону, ведущую за руку шалящего пути, а сама идея Ветра как фигурки голубого цвета - изображение Зефира в знаменитой боттичеллиевской «Весне». Редчайший для иконописи мотив, который мы обнаруживаем в иконе «Апокалипсис» - хоровод из четырёх фигур ангелов, держащихся за руки, отдалённо напомина- 
ет хоровод ангелов в «Мистическом Рождестве», которое Боттичелли написал в 1500 году ${ }^{56}$. Конечно, всё это не прямые, а косвенные совпадения. Но сходство некоторых мотивов весьма красноречиво.

Обнаруженные нами совпадения идей и мо тивов иконографической программы «Апокалипсиса» с главной идеей и некоторыми мотивами иллюстраций Боттичелли к «Божественной Комедии» Данте - своеобразные проявления воздействия искусства эпохи Ренессанса. Мы не можем пока точно сказать, по каким именно каналам шло это воздействие, но оно было, влияния проникали, усваивались и перерабатывались в соответствии с принятой системой иконописания ${ }^{57}$.

56 Картина имеет надпись на греческом языке: «Эту картину я, Александр, написал в конце 1500 года в неурядицах

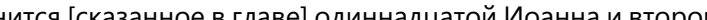
годе Апокалипсиса, в то время, когда дьявол на три с половиной года был выпущен. Затем он был закован в кандалы в соответствии с двенадцатой, и мы увидим его (попранным на земле], как на этой картинем. См... Дейм

см. Чинякова Г. - Аревняя Русови Запая Русских влиянии Апокалипсис XVI-XVII веков. Миниатюра, гравюра, икона, стенопись. М., 2017. С. 24. Преображенский А. С. Западные мотивы и формы в поствизантийской живописи Московии Предварительные размышления // Актуальные пробле-

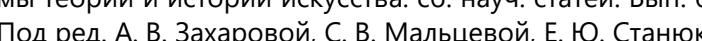
вич-Денисовой.-СПб: НП-Принт, 2016. С. 252-266.

БИБЛИОГРАФИЯ

1. Алексеев А. И. Под знаком конца времен: Очерки русской религиозности кон. XIV- нач. XVI в.-СПб. Алетейя, 2002.- 347 с

2. Алексеев А.И. О «Просветителе» и посланиях Иосифа Волоцкого // Вестник Церковной истории.2008. - № 2 (10). - C. 121-220.

3. Алпатов М. В. Памятник древнерусской живописи XV века - икона «Апокалипсис» Успенского собора Московского Кремля.-М.: Искусство, 1964.-110

4. Антонов Д.И., Майзульс М.Р. Демоны и грешники В древнерусской иконографии. Семиотика образа.-М.: Индрик, 2011. - 375 c

5. Буланин Д. М. Булев (Бюлов) Николай // Словарь книжников и книжности Древней Руси: [в 4 вып.]/ Рос. Акад. наук, Институт русской литературы (Пушкинский дом).-Вып. 2: Вторая половина XIV-XVI в. ч. 1: А-К / ред. Д. М. Буланин, Г. М. Прохоров. - Л. Наука, 1988.- 518 c

6. Гордиенко Э. А. Новгород в XVI веке и его духовная жизнь.-СПб:: Дмитрий Буланин (ДБ), 2001. - 466 с Деймминг Б. Сандро Боттичелли.-Кельн: Арт-родник, 2003. - 96 с
Обнаруженные параллели между иконой “Апокалипсис» и иллюстрациями Боттичелли к Данте заставляют склоняться к датировке иконы из Успенского собора не ранее 1490-1500 годов. Более того, учитывая, что распространение новых художественных идей и образов не происходит мгновенно, написанная в Москве икона могла быть создана уже после 1500 года, но не позднее первого десятилетия XVI века. Это произведение, несомненно, является памятником нового периода осмысления эсхатологических представлений, начавшегося после 1492 года. Она явилась своеобразным ответом православной Церкви на идеи хилиазма и осоне только в русский, но и западный культурологический контекст. Именно икона «Апокалипсис», написанная для Успенского собора, главного храма Московского царства, стоит у истоков русской традиции иллюстрирования Апокалипсиса в XVI веке. Можно предположить, что несохра нившаяся роспись Благовещенского собора Московского Кремля 1508 года следовала именно этому образцу, также как и фрески на тему Апокалипсиса, украсившие паперть Успенского собора в 1513 году.

8. Дионисий «живописец пресловущий». К 500-летию росписи Дионисия в соборе Рождества Богородицы Ферапонтова монастыря: Выставка произведений древнерусского искусства XV-XVI вв. из собраний музеев и библиотек России / Министерство культуры Российской Федерации; Государственная Третьяковская галерея / Редкол.: Е. В. Гладышева и др.М.: Северный паломник, 2002. - 303 с

9. Евсеева Л. М. Эсхатология 7000 года и возникновение высокого иконостаса // Иконостас. Происхождение -Развитие - Символика / Ред.-сост. А. М. Лидов.-М.: Прогресс-Традиция, 2000.-752 с.

0. Золотова Е. Ю. Жан Фуке.-М.: Изобразительно искусство, 1986. - 160 с

11. Зорич А. Апокалипсисы IX-XI вв. - URL: https:// www.medievalmuseum.ru/01mss/medieval_codexes_ apocalipsi.htm

2. Иконы Успенского собора Московского Кремля. Вторая половина XV-XVI век. Каталог.-М.: Федеральное государственное бюджетное учреждение культуры «Государственный историко-культурный музей-заповедник «Московский Кремль», 2016 _ 328 с
13. Качалова И. Я. История архитектуры Благовещенского собора // Благовещенский собор Московского Кремля. К 500-летиюо уникального памятника русской культуры. - М.: Искусство, 1990.-С. 6-20

14. Качалова И. Я. Монументальная живопись // Благовещенский собор Московского Кремля. К 500-ле гию уникального памятника русской культуры.- М. Искусство, 1990.-С. 21-44.

15. Качалова И. Я. Апокалипсис в стенописи Благовещенского собора // Благовещенский собор Московского Кремля: Материалы и исследор МоРедкол: Н. С. Владимирская и др-М. Государстен. «Московский Кремль», 1999.-С. 30-53.

16. Квливидзе Н. В. Икона «Благословенно воинство Небесного Царя» и её литературные параллели // Искусство христианского мира / Главн. ред. А. Салтыков-М: Издательство православного Свято-Тихоновского богословского института, 1998. - Вып. - С. $49-56$.

17. Лифшии Л.И. О границе понятий «дионисиевский стиль» и «стиль Дионисия» // Древнерусское искусство. Идея и образ. Опыты изучения византийского и древнерусского искусства: Материалы Международной научной конференции 1-2 ноября 2005 г./ Ред.-сост.: А. Л. Баталов, Э. С. Смирнова - М.: Се верный Паломник, 2005. - С. 126-162

18. Неволин Ю. А. Новое о кремлёвских художниках-миниатюристах и составе библиотеки Ивана Грозного // Советские архивы, 1982. - № 1.- С. 68-70.

19. Некрасов А. И. Древнерусское изобразительное искусство.- М.: Изогиз, 1937. - 395 с.

20. Нерсесян Л.В. 1999. К вопросу о происхождении и символическом содержании «О Тебе радуется» // Древнерусское искусство: Византия и Древняя Русь: К 100-летию Андрея Николаевича Грабара (1896-1990) / Отв. ред.: Э. С. Смирнова. -СПб.: Дмитрий Буланин (ДБ), 1999. - С. 380-398

21. Орлова М.А. «Рождество» из собрания П. Д. Корина // Древнерусское искусство. XIV-XV вв. /Отв. ред О. И. Подобедова.—М.: Наука, 1984.-С. 253-266 22. Попов Г. В. Живопись и миниатюра Москвы середи-
ны XV - начала XVI в.-М.: Искусство, 1975. -334 с.
23. ПСРЛ. Т. 13. Ч. 1.-СПб.: Типография И. Н. Скороходова, 1904.- 310 с.

24. Синицына Н. В. Третий Рим: истоки и эволюция русской средневековой концепции (XV-XVI вв).-М. Индрик, 1998.- 410 с

25. Скрынников Р. Г. Государство и церковь на Руси XIVXVI вв. - Новосибирск: Наука, 1991. - 393 с.

26. Смирнова Э. С. Московская иконо

7. Смирнова Э. С. Искусство книги в средневековой Руси. Лицевые рукописи Великого Новгорода. XV век.- М.: Северный Паломник, 2011._- 559 с.

28. Самойлова Т. Е. Благословенно воинство Небесного Царя.-М.: Прогресс-традиция, 2020.-68 с

29. Сорокатый В.М. Икона «Благословенно воинство Небесного Царя». Некоторые аспекты содержания // Древнерусское искусство. Византия и Древняя Русь. К 100-летию А. Н. Грабара / Отв ред. Э. С. Смирнова.-СПб: Дмитрий Буланин (ДБ), 1999.-С. 399-417.

30. Чинякова Г. П. Древняя Русь и Запад. Русский лицевой Апокалипсис XVI-XVII веков. Миниатюра, гравюра, икона, стенопись. - М.: БуксМАрт, 2017. - 374 с 31. Шалина И. А. Новгородские иконописцы и «хитре цы» эпохи владыки Макария // Искусство Великого Новгорода. Эпоха святителя Макария. Каталог выставки.-СПб.: Palace Editions, 2016.- С. 5-162.

Шалина И. А. Древнейшая псковская икона «Страшного суда" // В созвездии Льва. Сборник статей по древнерусскому искусству в честь Льва Исаа ковича Лифшица / Отв. ред. М. А. Орлова. - М.: Го сударствен

33. Herbert P. Horne. Botticelli: Painter of Florence. -

content/1047

4. Giraud-Labalte C. Der Wandteppich der Apokalypse.-Rennes 1982. - 259-270 p

Ronald W. Lightbown. Botticelli.- URL
https://www.britannica.com/biography/ https://www.britannica.com/

6öllner F. Botticelli.-C. H. Beck, 2009. 128 